\title{
Do North American Migratory Barren-Ground Caribou Subpopulations Cycle?
}

\author{
Eric Bongelli, ${ }^{1,2}$ Martha Dowsley, ${ }^{1}$ Victor M. Velasco-Herrera ${ }^{3}$ and Mitchell Taylor ${ }^{1}$
}

(Received 13 July 2019; accepted in revised form 21 May 2020)

\begin{abstract}
Unlike all other members of the deer family, subpopulations of barren-ground caribou (Rangifer tarandus groenlandicus) are typically sine-cyclic. We used Bayesian Information Criteria (BIC) to rank competing population dynamics models for 11 North American barren-ground caribou subpopulations. Nine of these subpopulations were best described as sine-cyclic with periods ranging from a minimum of 26 years (Bluenose-East and Porcupine) to a maximum of 55 years (Western Arctic); and amplitudes ranging from a minimum of 8455 (Cape Bathurst) to a maximum of 327432 (George River). Time series estimates of subpopulation abundance generated by the sine cycle models showed good correspondence to published subpopulation estimates of abundance for all nine sine-cyclic subpopulations $(r=0.978 ; p<0.001)$. Lack of demographic closure (migration between subpopulations) was evident in both of the subpopulations that were not identified as sine-cyclic. Barren-ground caribou subpopulation amplitudes were mostly determined by subpopulation total range size and summer range productivity $\left(\mathrm{R}^{2}=0.962 ; p<0.001\right)$ and subpopulation periods were mostly determined by amplitude, total range productivity, and land surface temperature $\left(\mathrm{R}^{2}=0.950 ; p<0.001\right)$. Time series estimates of subpopulation abundance generated from the respective environmental regression models were highly correlated $(r=0.964 ; p<0.001)$ to the published subpopulation estimates of abundance for the set of 9 sine-cyclic subpopulations. Extended ( $>3$ generations) subpopulation declines are a natural feature of cyclic barren-ground caribou subpopulations. Trends in species abundance based on pooled assemblages of asynchronous cyclic subpopulations should be interpreted with caution.
\end{abstract}

Key words: Bayesian Information Criteria; BIC; barren-ground caribou; species designation; COSEWIC; IUCN; cyclic species; cycle analysis; climate change; population dynamics; Rangifer tarandus groenlandicus; subpopulation

RÉSUMÉ. Contrairement à tous les autres membres de la famille des cervidés, les sous-populations de caribous de la toundra (Rangifer tarandus groenlandicus) suivent généralement un cycle sinusoïdal. Nous avons employé des critères d'information bayésiens (BIC) pour classer des modèles de dynamique des populations concurrentiels pour 11 sous-populations nord-américaines de caribous de la toundra. Neuf de ces sous-populations correspondaient mieux à une description de cycle sinusoïdal avec des périodes allant d'un minimum de 26 ans (Bluenose-Est et Porcupine) à un maximum de 55 ans (Arctique de l'Ouest); et des amplitudes allant d'un minimum de 8455 (cap Bathurst) à un maximum de 327432 (rivière George). Les estimations des séries chronologiques de l'abondance des sous-populations obtenues à l'aide des modèles de cycles sinusoïdaux ont affiché une bonne correspondance par rapport aux estimations publiées de l'abondance des sous-populations pour l'ensemble des neuf sous-populations de cycle sinusoïdal $(r=0,978 ; p<0,001)$. Le manque de fermeture démographique (migration entre les sous-populations) était évident dans les deux sous-populations qui n'étaient pas considérées comme suivant un cycle sinusoïdal. L'amplitude des sous-populations de caribous de la toundra était principalement déterminée par la taille de l'aire de répartition totale et la productivité de l'aire d'estivage $\left(\mathrm{R}^{2}=0,962 ; p<0,001\right)$, et les périodes de sous-populations étaient principalement déterminées par l'amplitude, la productivité de l'aire de répartition totale et la température en surface des terres $\left(\mathrm{R}^{2}=0,950 ; p<0,001\right)$. Les estimations des séries chronologiques de l'abondance des sous-populations produites au moyen des modèles respectifs de régression environnementale étaient fortement corrélées $(r=0,964 ; p<0,001)$ aux estimations publiées de l'abondance des sous-populations pour l'ensemble des neuf sous-populations de cycle sinusoïdal. Les déclins prolongés ( $>3$ générations) de sous-populations sont une caractéristique naturelle des sous-populations cycliques de caribous de la toundra. Les tendances caractérisant l'abondance des espèces en fonction d'assemblages regroupés de sous-populations cycliques asynchrones devraient être interprétées avec prudence.

Mots clés : critères d'information bayésiens; BIC; caribou de la toundra; désignation des espèces; COSEPAC; UICN; espèces cycliques; analyse des cycles; changement climatique; dynamique des populations; Rangifer tarandus groenlandicus; sous-population

Traduit pour la revue Arctic par Nicole Giguère.

\footnotetext{
${ }^{1}$ Faculty of Science and Environmental Studies, Department of Geography and Environment, Lakehead University, 955 Oliver Road, Thunder Bay, Ontario P7B 5E1, Canada

${ }^{2}$ Corresponding author: esbongel@lakeheadu.ca

${ }^{3}$ Institute of Geophysics of the National Autonomous University of Mexico (UNAM), Space Sciences, Av Universidad 3000, Cd. Universitaria, Coyoacán, Ciudad de México, Mexico

(C) The Arctic Institute of North America
} 


\section{INTRODUCTION}

Our consideration of barren-ground caribou (Rangifer tarandus groenlandicus) population dynamics uses the terminology suggested by Cronin (2006) for contiguous wildlife subpopulations as demographically distinct components of the larger North American barren-ground caribou population. However, not all barren-ground caribou subpopulations are demographically distinct (Nagy et al., 2011; COSEWIC, 2016; ADFG, 2017; Adamczewski et al., 2019), and some barren-ground caribou subpopulations (e.g., island subpopulations and the Dolphin-Union subpopulation) are sufficiently segregated that they are genetically distinct from even the most proximate subpopulations (McFarlane et al., 2016). Since an exchange of only one migrant per subpopulation per generation is sufficient to homogenize gene pools (Mills and Allendorf, 1996), contiguous continental subpopulations of barren-ground caribou are, as expected, genetically indistinguishable (McFarlane et al., 2016) except for the Dolphin Union, Southampton Island, and Baffin Island subpopulations, which are seasonally reproductively isolated. Our use of the term "subpopulation" is strictly in a demographic (not genetic) context and assumes demographic closure is sufficient to render exchange with other subpopulations negligible with respect to population dynamics.

Periodic subpopulation estimates have documented that barren-ground caribou subpopulations exhibit regular fluctuations in abundance that have sometimes been termed cyclic (Gunn and Miller, 1986; Couturier et al., 1990; Russell et al., 2002; Gunn, 2003; Wilson and Reeder, 2005; GY, 2015; COSEWIC, 2016). Traditional ecological knowledge (TEK) also confirms that regular periodic changes in abundance are characteristic of this species (Hemming, 1975; Zalatan et al., 2006; Council of Canadian Academies, 2014; Legat et al., 2014; Hebert, 2015). The factors that regulate barren-ground caribou subpopulation dynamics are not well understood (Messier et al., 1988; Klein, 1991), but forage availability, predators, insect harassment, pathogens, decadal winter severity, habitat disturbance (e.g., development and forest fires), and climate change are all believed to influence population dynamics in other species and could also drive or influence barrenground caribou population cycles (Kelsall, 1968; Skoog, 1968; Hemming, 1971; Fancy et al., 1989; GNWT, 2007; Fauchald et al., 2017).

Barren-ground caribou are a population with 14 relatively discrete North American continental subpopulations that extend from Alaska across the continental mainland and archipelago of Canada (Nagy et al., 2011; COSEWIC, 2016; Parlee et al., 2018). All subpopulations spend at least a portion of the year on the barren-lands, with mainland migratory subpopulations dividing their time between the tundra and boreal forest (e.g., Qamanirjuaq), and tundra-wintering subpopulations spending the entire year on the tundra (e.g., Cape Bathurst and Dolphin-Union). Barren-ground caribou partake in regular seasonal migrations rather than remain within a single well-defined home range throughout the year (Fancy et al., 1989; RCGS, 2010; COSEWIC, 2016; Nicholson et al., 2016). Barren-ground caribou are a birth-pulse species (Caughley, 1977). The calving period is synchronized for each subpopulation and generally occurs over a two-week period in June (Nagy et al., 2011; Nagy and Campbell, 2012; COSEWIC, 2016). Mainland migratory barren-ground caribou generally migrate north towards the Arctic coast to calve on the barren-lands and occur throughout the summer and early autumn on the tundra in the Southern Arctic ecozone (COSEWIC, 2016). Females generally produce one calf annually, usually beginning at age $2+$, although poor health or nutrition may cause adult females of any age not to conceive or produce viable calves (COSEWIC, 2016). Mainland populations usually winter in the boreal forest within the Taiga Cordillera, Taiga Plains, or Taiga Shield ecozones (Kelsall, 1968; Skoog, 1968; Hemming, 1971; Fancy et al., 1989; GNWT, 2007; COSEWIC, 2016). Fluctuations in abundance influence the size of seasonal ranges and the length of migration patterns (COSEWIC, 2016). As subpopulation abundance increases, seasonal ranges expand. Conversely, as subpopulation abundance declines, seasonal ranges contract towards the traditional calving areas (Hemming, 1975). The contraction of the home range has the net effect of allowing for the recovery of previously overused seasonal pastures (Hemming, 1975; COSEWIC, 2016).

On the summer range, barren-ground caribou forage on a variety of plants such as willows, grasses, dwarf birch, mountain avens, Arctic sorrel, mushrooms, moss campion, and berries (Thorpe et al., 2001; Dumond 2007), but lichen (dominated by Cladina sp.) is the primary forage for barren-ground caribou on the winter range (Thomas and Hervieux, 1986; Théau et al., 2005; Collins, 2006; Andersen and Johnson, 2014; Rickbeil et al., 2017), constituting approximately $60 \%-80 \%$ of their diet (Thomas and Hervieux, 1986; Jandt et al., 2003; Andersen and Johnson, 2014). Manseau et al. (1996) suggest that quality and volume of available forage on summer pastures are the primary regulators of physical body condition and population abundance. Gunn (2003) suggested that delayed feedbacks in herbivore-forage dynamics might be the primary driver in barren-ground caribou cycling. Others (e.g., Klein, 1970, 1986; Parker et al., 2005) suggest barren-ground caribou abundance is mainly determined by winter foraging conditions. Within a given subpopulation range, the availability of forage is influenced by range productivity, grazing intensity, trampling, and in winter range only, forest fires (Ahti, 1959; Scotter, 1964; Zalatan et al., 2006; Collins et al., 2011; Anderson and Johnson, 2014).

Direct weather events such as snow depth and icing can affect the ability of barren-ground caribou to access vegetation (Weladji and Holland, 2003). The frequency and severity of direct weather events are influenced by biome type and large-scale patterns in climatic activity such as 
the El Niño Southern Oscillation (ENSO), the Atlantic Multidecadal Oscillation (AMO) the Arctic Oscillation (AO), the Pacific Decadal Oscillation (PDO), and longerterm progressive climate trends (COSEWIC, 2016). The $\mathrm{AO}$ has a strong negative correlation with population trends for the Porcupine and Central Arctic subpopulations (Joly et al., 2011).

North America's barren-lands are comprised of five main biome types: alpine tundra, shrub tundra, herb tundra, forest tundra, and boreal forest (Dyke, 2005). These five biomes are characterized by relatively low temperatures, short growing seasons, acidic nutrientpoor soils with patchy vegetation, and slow vegetation regeneration rates (Archer and Tieszen, 1980; Payette et al., 2001). The western Arctic of Alaska and Yukon is predominantly characterized by boreal forest and alpine tundra, while the eastern Canadian Arctic is predominantly shrub, herb, and forest tundra at similar latitudes (Dyke, 2005). Primary productivity follows a SW to NE gradient of decreasing net primary productivity (NPP) in northern North America (Qian, 1999; Hicke et al., 2002; Gillman et al., 2015). The gradient of NPP is driven by regional temperature trends and is clearly illustrated by the treeline isopleth. The mechanisms responsible for regional temperature trends are marine in origin and include sea surface temperature as mediated by ENSO events, the PDO, and the AMO (Liu et al., 2015).

Like all naturally occurring species, barren-ground caribou subpopulation numbers are ultimately regulated by density-dependent reductions in calf production, survival rates or both (Demerec, 1957; Tanner 1966; Caughley, 1977; McCullough, 1979, 1999; Fowler, 1981; Kie and White, 1985; Skogland, 1985; Clutton-Brock et al., 1987; Boyce, 1989; Messier et al., 1988; Bowyer et al., 2014). The discrete logistic equation (linear density effects) can exhibit convergence on carrying capacity, converging cycles to carrying capacity, stable limit cycles, increasing oscillations to extinction, and even chaos depending on the population's maximum growth rate $\left(\lambda_{\max }\right)$ (May, 1976; Renshaw, 1991). The maximum and minimum annual rates of population growth (or decline) for barren-ground caribou vary between subpopulations, but typically do not exceed $\lambda=1.17$ and are not less than $\lambda=0.83$ (Gunn, 2003). At barren-ground caribou $\lambda_{\max }(\leq 1.17)$, the logistic equation suggests that caribou (like other deer species) would, ceteris paribus, converge on range carrying capacity (May, 1976; Renshaw, 1991; Vandermeer, 2010). Stable limit cycles are not observed until $\lambda_{\max }$ is above 2.57 (May, 1976; Renshaw, 1991), which is more than double the maximum observed annual population growth rate for barren-ground caribou. Although both science and TEK agree that barren-ground caribou subpopulations experience regular fluctuations in population abundance (Meldgaard, 1986; Ferguson et al., 1998; Klein, 1991; Russell et al., 2002; Gunn, 2003; GY, 2015), no previous study has attempted to determine if these fluctuations are regular cycles.
Several barren-ground caribou subpopulations have experienced declines in abundance over approximately the last two decades (Gunn et al., 2010; CARMA, 2016; COSEWIC, 2016). Both the Committee on the Status of Endangered Wildlife in Canada (COSEWIC) and the International Union for Conservation of Nature (IUCN) have responded to the declines in subpopulation abundance by designating barren-ground caribou species as "threatened" and "vulnerable" (COSEWIC, 2016; IUCN, 2016). COSEWIC (2016) suggests barren-ground caribou subpopulation cycles are either synchronized or are currently influenced by a common factor that has interrupted their natural population trajectory. Alternatively, differences in subpopulation cycle periods could cause apparent pooled-group trends that were solely the result of damping and resonance (non-synchronous) subpopulation cycling. Periods of synchrony might be coincidental rather than caused by some factor affecting all barren-ground caribou subpopulations simultaneously.

We identified 11 North American barren-ground caribou subpopulations that had a sufficient time series of subpopulation estimates and compared linear, exponential, logistic, sine-cyclic, and wavelet cyclic functions using regression and model selection methods that ranked functions considering both fit and number of function parameters for each subpopulation. We estimated the period and amplitude for subpopulations that were best described as sine-cyclic. We pooled extrapolations of sine-cyclic subpopulations to examine the effects of damping and resonance on the population dynamics of the pooled time series. We compared the expected (extrapolated) sine-cyclic subpopulation estimates with the observed subpopulation survey estimates to test correspondence of the sine-cycle classification. We used stepwise regression to develop a suite of candidate models that employed subpopulation range specific environmental parameters, and used a model selection criterion to identify our best model. We then compared the environmental model expected values of subpopulation abundance to the observed subpopulation estimates as a test of model correspondence to nature.

\section{METHODS}

We identified five functions (linear, exponential, logistic, sine-cyclic, and wavelet; Fig. 1) as potential descriptions for the time series estimates of barren-ground caribou subpopulation abundance. We did not consider subpopulations that had fewer than five subpopulation estimates. Inspection of the Porcupine time series subpopulation estimates suggested a progressive increase in subpopulation abundance through consecutive cycles. We added a linear increase variable to the sine function for the Porcupine time series subpopulation estimates to test for progressive increase in the subpopulation cycle. We identified the best function based on a combination of statistical procedures that included least squares linear 


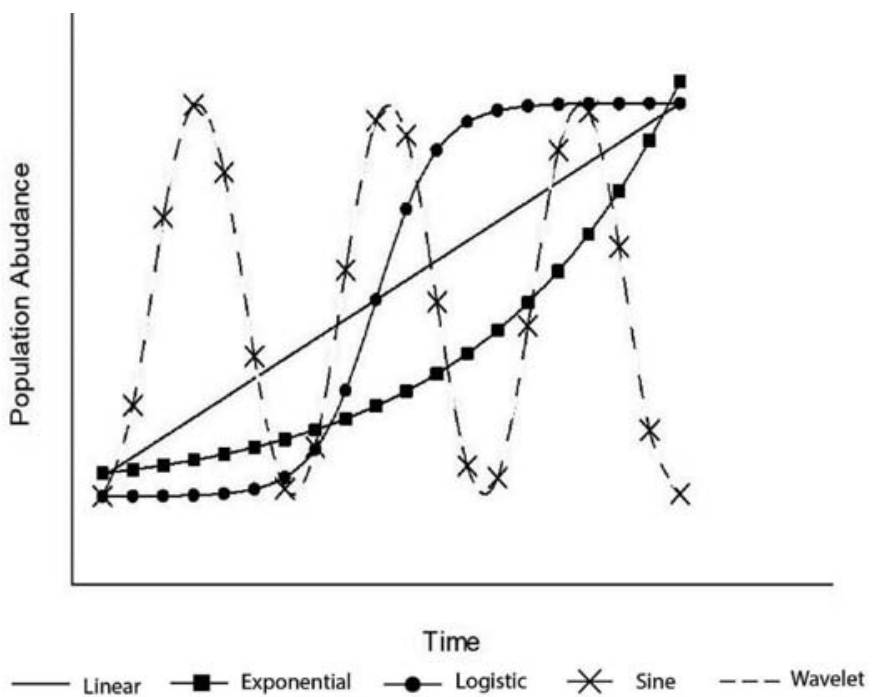

FIG. 1. Five distinct functions (linear, exponential, logistic, sine, and wavelet) were fit to the time series subpopulation survey estimates of 11 discrete subpopulations of barren-ground caribou. Linear, exponential, logistic, and sine functions were fit using IBM SPSS statistics (IMB Corp., 2017). The wavelet function was fit following Torrence and Compo (1998) methodology. We rejected function fits that did not result in a significant correlation $(p \geq$ 0.05 ) and those that resulted in a non-normal distribution of residuals (S-W $(p) \leq 0.05$ ). We ranked functions based on their associated $\triangle$ BIC (Bayesian Information Criterion) values. Our function selection criteria identified functions with $\Delta \mathrm{BIC}<2$ as equivalent functions (i.e., could not discriminate between them).

regression and non-linear regression (IBM Corp., 2017), Shapiro-Wilk (S-W) test for normality of residuals (IBM Corp., 2017), and Bayesian Information Criteria (BIC) (Schwartz, 1978). We rejected function fits that did not result in a significant correlation $(p \geq 0.05)$ and those that resulted in a non-normal distribution of residuals ( $\mathrm{S}-\mathrm{W}$ $[p \leq 0.05])$.

Structurally dissimilar regression models with similar correlation coefficients can be objectively ranked using Akaike's Information Criterion (AIC) and BIC criteria (Sugiura, 1978; Hurvich and Tsai, 1989; Burnham and Anderson, 2002). We used the identity $-2 \log *(\log$ likelihood $)=\mathrm{n}^{*} \log (\mathrm{RSS} / \mathrm{n})$ to formulate equations for AIC and BIC (Venables and Ripley, 2002) that could be calculated from the number of subpopulation estimates (n), the number of function parameters $(\mathrm{k})$, and the regression sum of squares (RSS) associated with function fits for each subpopulation:

$$
\begin{gathered}
A I C=n * \log \left(\frac{R S S}{n}\right)+2 k \\
B I C=n * \log \left(\frac{R S S}{n}\right)+k * \log (n)
\end{gathered}
$$

As the number of parameters $(\mathrm{k})$ in the candidate model increases relative to the sample size (n), AIC becomes negatively biased against simple models (small k) (Sugiura, 1978). This bias can lead to overfitting (i.e., inappropriate selection of complex models over simpler models) (Sugiura, 1978; Hurvich and Tsai, 1989). Hurvich and Tsai (1989) provided a corrected criterion for bias at low values of $\mathrm{n}$ :

$$
A I C c=n \log \left(\frac{R S S}{n}\right)+2 k+\left(\frac{2 k^{2}+2 k}{n-k-1}\right) \text { eq. } 3
$$

We compared the AICc and BIC penalty terms (eqs. 2 and 3) to better understand the differences between the two model selection criteria for the range of sample size (n) and model parameters $(\mathrm{k})$ relevant to the caribou subpopulation time series estimates and population functions we were comparing (Fig. 2). At low $\mathrm{n} / \mathrm{k}$ ratios, the AICc parameter penalty for one additional parameter for simple models (low K) was much greater than the parameter penalty for more complex models (higher K) (Fig. 2), which caused a strong bias in favor of selecting simple models for a portion of the range of $\mathrm{n} / \mathrm{k}$ values from our study (Fig. 2). The BIC parameter penalties were approximately proportional and thus unbiased through the same $\mathrm{n} / \mathrm{k}$ range (Fig. 2). We were unable to find a previous mention of this issue, perhaps because our application employed minimal sample sizes to compare relatively simple models.

The BIC procedure identifies the best model and is the most appropriate choice when study purpose is to identify the best model (Aho et al., 2014). Compared to AICc, BIC is parsimonious and thus more prone to underfitting (Dziak et al., 2020). We based function (model) selection on BIC only and thus viewed the selection of more complex models (e.g., sine-cyclic) over simpler models (e.g., exponential) to be conservative. We ranked functions based on their associated $\triangle \mathrm{BIC}$ values. Our function selection criteria identified functions $\Delta \mathrm{BIC}<2$ as equivalent (could not discriminate between them) functions (Burnham and Anderson, 2002).

We generated time series estimates of pooled subpopulations (i.e., sum of all subpopulations we considered to be sine-cyclic) by extrapolating the sine function for each sine-cyclic subpopulation. We examined the pooled subpopulation time series for evidence of subpopulation synchrony or harmonics. We tested the correspondence of the sine functions to nature by comparing the sine function extrapolation to the time series of observed estimates of all the subpopulations considered sine-cyclic.

We utilized correlation and regression to explore the relationships between sine-cyclic subpopulation cycle period length and amplitude and selected subpopulation seasonal range attributes (i.e., total range area, tundra [summer] range area, forest [winter] range area, tundra percentage, mean land surface temperature [LST], NPP, and normalized difference vegetation index [NDVI]). We generated a correlation matrix of range attributes and subpopulation cycle characteristics (period and amplitude). We identified physical and biological range attributes that were significantly correlated $(p \leq 0.05)$ to period and to amplitude independently. Considering the results 

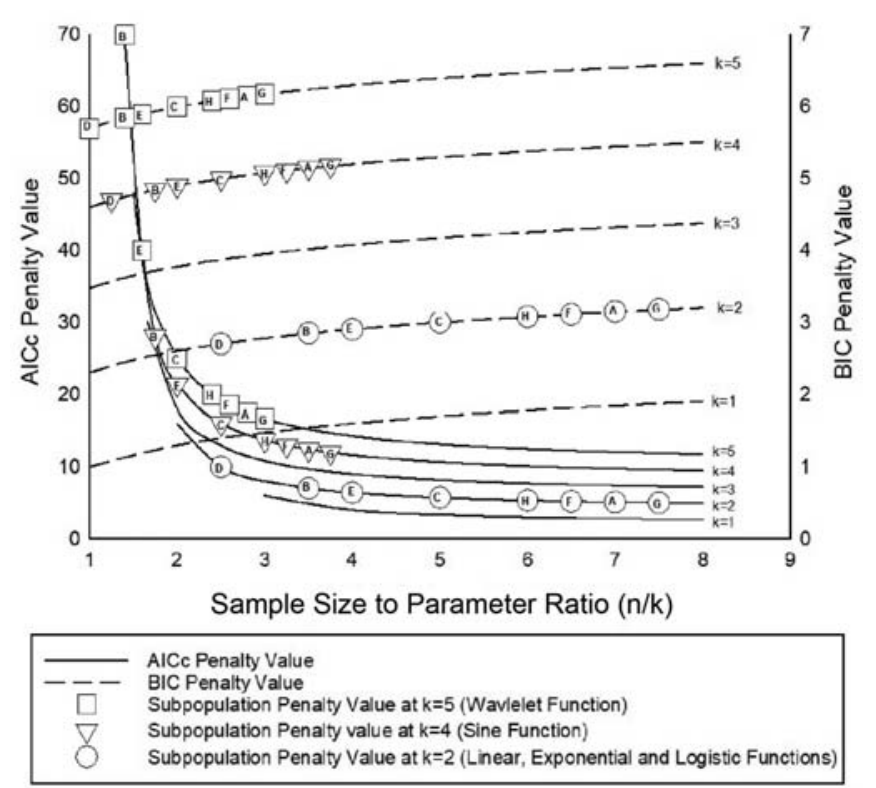

FIG. 2. The progression of penalties for parameters associated with $\mathrm{AICc}$ and BIC criteria was compared for a range of subpopulation estimates (n) to population function parameter $(\mathrm{k})$ ratios $(\mathrm{n} / \mathrm{k})$ that included 11 subpopulations of barren-ground caribou. Subpopulations were identified alphabetically with identical letters for subpopulations with identical $(\mathrm{n} / \mathrm{k})$ values: George River (A), Leaf River (B), Qamanirjuaq (C), Bathurst (A), Bluenose-East (D), Bluenose-West (E), Cape Bathurst (B), Porcupine (F), Central Arctic (G), Teshekpuk Lake (H), and Western Arctic (F). The isoclines for function parameter values of $1-5$ are shown for both AICc and BIC total penalties (parameter penalty + sample size correction). Subpopulation AICc and BIC total penalty values for their corresponding $\mathrm{n} / \mathrm{k}$ ratios show a relatively constant parameter penalty for BIC, but dramatically higher penalties for more complex models (higher k) than for more simple models (lower k) for AICc. AICc demonstrates strong model selection bias for simple models in the small sample size tail of the $\mathrm{n} / \mathrm{k}$ axis

of the correlation matrix, we explored main and twoway interaction effects using stepwise linear regression to develop a suite of models of subpopulation period and amplitude as a function of physical and environmental variables. We ranked models using BIC and retained only models with $\triangle \mathrm{BIC}<2$. We then compared models with $\Delta \mathrm{BIC}<2$ based on parsimony, fit (contribution to $\mathrm{R}^{2}$ ), and deviation from the top model $(\triangle \mathrm{BIC}=0)$. Using our preferred linear regression environmental model for period and for amplitude, we generated subpopulation specific regression estimates of period and amplitude. We compared the environmental regression estimates to the sine function estimates of period and amplitude. Additionally, we used the environmental model estimates of period and amplitude to generate time series estimates of subpopulation numbers to compare against subpopulation estimates as a test of correspondence to nature.

NDVI is a commonly used remote sensing method for assessing and monitoring ecological productivity. NDVI has been used to monitor ecosystem health, faunal habitat, faunal distribution and condition, forage quality, and disease risk (Leyequien et al., 2007). The NDVI index is calculated from satellite-monitored ground pixel radiance in specific spectral bands visible light (VIS) $(0.4$ to $0.7 \mu \mathrm{m})$ and nearinfrared light (NIR) $(0.7$ to $1.1 \mu \mathrm{m})$ (Schmid, 2017). NDVI provides an estimation of the density of vegetation within a given pixel based on the reflectance of VIS and NIR light. NDVI is calculated as NDVI $=(\mathrm{NIR}-\mathrm{VIS}) /(\mathrm{NIR}+\mathrm{VIS})$ (Weier and Herring, 2000). NDVI values for individual pixels range from 0.1 (stone, sand, and snow), 0.3 (sparse vegetation), 0.6 (temperate forests) to $0.8-1.0$ (the highest possible density of vegetation [e.g., rainforest]). Negative values indicate the presence of water or ice (Schmid, 2017).

NPP is a fundamental measure of change in terrestrial biological activity (NEO, 2018). Regional NPP has been used to define the carrying capacity of a specific region (Gonsamo and Chen, 2018). The spatial variability of NPP carbon ranges from approximately $1000 \mathrm{~g} / \mathrm{m}^{3}$ per year (evergreen tropical rainforests) to less than $30 \mathrm{~g} / \mathrm{m}^{3}$ per year (deserts) (NEO, 2018). NPP is equal to carbon uptake by vegetation through photosynthesis (Gross Primary Productivity [GPP]) minus carbon lost to respiration (RE) and is calculated as: NPP = GPP - RE (GLOBE, 2017; NEO, 2018). NPP is designed to produce an accurate regular measure of terrestrial vegetation growth (NEO, 2018).

The distribution of vegetation in the Arctic is largely controlled by climate, particularly summer temperatures (Raynolds et al., 2008). LST is a non-specific term that indicates the temperature of all objects on the existing surface (Anbazhagan and Paramasivam, 2016). LST is sensitive to changing surface conditions ((A)ATSR, 2009) and can be used to monitor vegetation at a local and global level (Yu et al., 2018). Arctic vegetation has increased in response to an increase in summer temperatures (Raynolds et al., 2008). We used NDVI, NPP, and LST as estimates of ecological productivity on the seasonal and total ranges of barren-ground caribou.

Google Earth Engine (GEE) is a web-based remote sensing platform that is able to carry out spatial and temporal aggregations of satellite imagery (Sidhu et al., 2018). GEE provides public access to satellite archives from Landsat 4-8, Sentinel 1-2, MODIS to Aster, and World Health Indicators System (WHIS), which provide climate, land cover, and topographic data (Schmid, 2017). GEE allows for the spatial and temporal manipulation of these datasets using a JavaScript and Python application programming interface. We used ArcMap 10.8 to visualize, transform, and map spatial data. We geo-referenced subpopulation home ranges based on COSEWIC and CircumArctic Rangifer Monitoring and Assessment Network (CARMA) maps of barren-ground caribou subpopulations (CARMA, 2016; COSEWIC, 2016) using the North American Lambert Conformal Conic projected coordinate system. We classified the summer range as the proportion of the range north of the treeline and winter range as the proportion of the range south of the treeline. We used GEE to query LST, NDVI, and NPP data for the seasonal ranges and total ranges of the 11 barren-ground caribou subpopulations that we considered (Appendix S1). We filtered the data by date to retain only data from May to August, which we assumed would correspond to the main portion of the growing season on both the barren-lands 
TABLE 1. Using SPSS linear and non-linear regression, we compared the utility of five functions-linear $(\mathrm{k}=2)$, exponential $(\mathrm{k}=2)$, logistic $(\mathrm{k}=2)$, sine $(\mathrm{k}=4)$, and wavelet $(\mathrm{k}=5)$ - to describe changes in a time series of subpopulation estimates for 11 subpopulations (George River, Leaf River, Qamanirjuaq, Bathurst, Bluenose-East, Bluenose-West, Cape Bathurst, Porcupine, Central Arctic, Teshekpuk Lake, and Western Arctic) of barren-ground caribou. The regression residual sum of squares (RSS) associated with each function was used to calculate Bayesian Information Criteria (BIC) for each of the 11 subpopulations. Goodness of fit $\left(\mathrm{R}^{2}\right)$ and the F-statistic were determined for each function. The Shapiro-Wilk (S-W) statistic was used to assess the normality of residual values. The number (n) of population estimates for each subpopulation estimate ranged from 5 to 15 . The number of parameters for each function (k) ranged from 2 to $5 . \triangle \mathrm{BIC}$ values less than 2.0 are bolded. We added a linear increase variable to the sine function for the Porcupine time series subpopulation estimates to test for progressive increase in the subpopulation cycle.

\begin{tabular}{|c|c|c|c|c|c|c|c|c|}
\hline Function & $\mathrm{R}^{2}(p)$ & $\mathrm{S}-\mathrm{W}(p)$ & RSS & $\Delta \mathrm{BIC}$ & $\mathrm{R}^{2}(p)$ & $\mathrm{S}-\mathrm{W}(p)$ & RSS & $\Delta \mathrm{BIC}$ \\
\hline & \multicolumn{4}{|c|}{ George River $(\mathrm{n}=14)$} & \multicolumn{4}{|c|}{ Leaf River $(\mathrm{n}=7)$} \\
\hline Linear & $0.022(0.613)$ & 0.043 & $6.459 \mathrm{E} 11$ & 15.422 & $0.335(0.173)$ & 0.359 & $1.693 \mathrm{E} 11$ & 8.658 \\
\hline Exponential & $0.013(0.694)$ & 0.028 & $6.520 \mathrm{E} 11$ & 15.479 & $0.257(0.246)$ & 0.253 & $1.907 \mathrm{E} 11$ & 9.021 \\
\hline Logistic & $0.316(0.036)$ & 0.667 & 4.514E 11 & 14.625 & $0.632(0.032)$ & 0.026 & $9.356 \mathrm{E} 10$ & 8.544 \\
\hline Sine & $0.946(<0.001)$ & 0.950 & $3.989 \mathrm{E} 10$ & 0.000 & $0.978(<0.001)$ & 0.947 & $5.627 \mathrm{E} 9$ & 0.000 \\
\hline \multirow[t]{2}{*}{ Wavelet } & $0.915(<0.001)$ & 0.669 & $1.625 \mathrm{E} 11$ & 10.472 & $\mathrm{n} / \mathrm{a}$ & $\mathrm{n} / \mathrm{a}$ & $\mathrm{n} / \mathrm{a}$ & $\mathrm{n} / \mathrm{a}$ \\
\hline & \multicolumn{4}{|c|}{ Qamanirjuaq $(\mathrm{n}=10)$} & \multicolumn{4}{|c|}{ Bathurst $(n=14)$} \\
\hline Linear & $0.479(0.027)$ & 0.217 & $9.633 \mathrm{E} 10$ & 6.301 & $0.167(0.147)$ & 0.025 & $2.247 \mathrm{E} 11$ & 9.473 \\
\hline Exponential & $0.379(0.058)$ & 0.112 & $1.165 \mathrm{E} 11$ & 7.127 & $0.123(0.218)$ & 0.008 & $2.373 \mathrm{E} 11$ & 9.804 \\
\hline Logistic & $0.794(<0.001)$ & 0.262 & $3.810 \mathrm{E} 10$ & 3.784 & $0.447(0.009)$ & 0.762 & $1.491 \mathrm{E} 11$ & 10.772 \\
\hline Sine & $0.922(<0.001)$ & 0.409 & $1.425 \mathrm{E} 10$ & 0.000 & $0.874(<0.001)$ & 0.316 & $3.998 \mathrm{E} 10$ & 0.280 \\
\hline \multirow[t]{2}{*}{ Wavelet } & $0.837(0.002)$ & 0.917 & $1.213 \mathrm{E} 11$ & 10.302 & $0.917(<0.001)$ & 0.483 & $2.688 \mathrm{E} 10$ & 0.000 \\
\hline & \multicolumn{4}{|c|}{ Bluenose-East $(\mathrm{n}=5)$} & \multicolumn{4}{|c|}{ Bluenose-West $(\mathrm{n}=8)$} \\
\hline Linear & $0.072(0.662)$ & 0.187 & $6.984 \mathrm{E} 09$ & 20.965 & $0.831(0.002)$ & 0.562 & $2.133 \mathrm{E}+09$ & 6.245 \\
\hline Exponential & $0.055(0.700)$ & 0.204 & $7.124 \mathrm{E}+09$ & 21.008 & $0.759(0.004)$ & 0.135 & $3.090 \mathrm{E}+09$ & 7.533 \\
\hline Logistic & $0.469(0.202)$ & 0.955 & $8.309 \mathrm{E}+09$ & 19.754 & $0.974(<0.001)$ & 0.263 & $3.220 \mathrm{E}+08$ & 14.051 \\
\hline Sine & $0.999(<0.001)$ & 0.883 & $2.352 \mathrm{E}+05$ & 0.000 & $0.983(<0.001)$ & 0.125 & $2.101 \mathrm{E}+08$ & 0.000 \\
\hline \multirow[t]{2}{*}{ Wavelet } & $\mathrm{n} / \mathrm{a}$ & $\mathrm{n} / \mathrm{a}$ & $\mathrm{n} / \mathrm{a}$ & $\mathrm{n} / \mathrm{a}$ & $\mathrm{n} / \mathrm{a}$ & $\mathrm{n} / \mathrm{a}$ & $\mathrm{n} / \mathrm{a}$ & $\mathrm{n} / \mathrm{a}$ \\
\hline & \multicolumn{4}{|c|}{ Cape Bathurst $(\mathrm{n}=7)$} & \multicolumn{4}{|c|}{ Teshekpuk Lake $(\mathrm{n}=12)$} \\
\hline Linear & $0.835(0.004)$ & 0.101 & $4.580 \mathrm{E}+07$ & 6.666 & $0.737(<0.001)$ & 0.334 & $9.542 \mathrm{E}+08$ & 1.068 \\
\hline Exponential & $0.757(0.011)$ & 0.046 & $6.952 \mathrm{E}+07$ & 7.935 & $0.644(0.001)$ & 0.949 & $1.314 \mathrm{E}+09$ & 2.736 \\
\hline Logistic & $0.983(<0.001)$ & 0.0 .338 & $4.627 \mathrm{E}+06$ & 14.678 & $0.801(<0.001)$ & 0.632 & $7.289 \mathrm{E}+08$ & 0.000 \\
\hline Sine & $0.989(<0.001)$ & 0.588 & $2.932 \mathrm{E}+06$ & 0.000 & $0.845(<0.001)$ & 0.648 & $5.611 \mathrm{E}+08$ & 0.459 \\
\hline \multirow[t]{2}{*}{ Wavelet } & $\mathrm{n} / \mathrm{a}$ & $\mathrm{n} / \mathrm{a}$ & $\mathrm{n} / \mathrm{a}$ & $\mathrm{n} / \mathrm{a}$ & $\mathrm{n} / \mathrm{a}$ & $\mathrm{n} / \mathrm{a}$ & $\mathrm{n} / \mathrm{a}$ & $\mathrm{n} / \mathrm{a}$ \\
\hline & \multicolumn{4}{|c|}{ Porcupine $(\mathrm{n}=13)$} & \multicolumn{4}{|c|}{ Porcupine $($ Sine + Linear Term) $(n=13)$} \\
\hline Linear & $0.601(0.002)$ & 0.827 & $1.012 \mathrm{E}+12$ & 29.358 & $0.601(0.002)$ & 0.827 & $1.012 \mathrm{E}+12$ & 33.522 \\
\hline Exponential & $0.604(0.001)$ & 0.875 & $6.449 \mathrm{E}+09$ & 0.811 & $0.604(0.001)$ & 0.875 & $6.449 \mathrm{E}+09$ & 4.967 \\
\hline Logistic & $0.576(0.002)$ & 0.033 & $6.551 \mathrm{E}+09$ & 0.900 & $0.576(0.002)$ & 0.003 & $6.551 \mathrm{E}+09$ & 5.064 \\
\hline Sine & $0.770(<0.001)$ & 0.934 & $3.764 \mathrm{E}+09$ & 0.000 & $0.894(<0.001)$ & 0.751 & $1.478 \mathrm{E}+09$ & 0.000 \\
\hline \multirow[t]{2}{*}{ Wavelet } & $0.672(<0.001)$ & 0.224 & $5.377 \mathrm{E}+09$ & 3.127 & $0.672(<0.001)$ & 0.224 & $5.377 \mathrm{E}+09$ & 7.292 \\
\hline & \multicolumn{4}{|c|}{ Central Arctic $(\mathrm{n}=15)$} & \multicolumn{4}{|c|}{ Western Arctic $(\mathrm{n}=13)$} \\
\hline Linear & $0.539(0.002)$ & 0.008 & $2.401 \mathrm{E}+09$ & 10.214 & $0.092(0.314)$ & 0.087 & $2.004 \mathrm{E}+11$ & 13.632 \\
\hline Exponential & $0.488(0.003)$ & 0.002 & $2.683 \mathrm{E}+09$ & 4.449 & $0.070(0.382)$ & 0.0 .81 & $2.054 \mathrm{E}+11$ & 13.773 \\
\hline Logistic & $0.647(<0.001)$ & 0.003 & $1.834 \mathrm{E}+09$ & 2.852 & $0.595(0.001)$ & 0.111 & $8.917 \mathrm{E}+10$ & 9.313 \\
\hline Sine & $0.636(<0.001)$ & 0.636 & $1.890 \mathrm{E}+09$ & 4.840 & $0.972(<0.001)$ & 0.051 & $1.207 \mathrm{E}+10$ & 0.000 \\
\hline Wavelet & $0.921(<0.001)$ & 0.609 & $7.310 \mathrm{E}+08$ & 0.000 & $0.945(<0.001)$ & 0.744 & $1.626 \mathrm{E}+10$ & 2.796 \\
\hline
\end{tabular}

and forested areas (Post et al., 2009). LST and NPP data were acquired from MODIS satellite imagery at a $1 \mathrm{~km}$ pixel resolution from $2000-18$ and $2000-14$, respectively. NDVI data from 2000 to 2016 were acquired from Landsat 7 at a $30 \mathrm{~m}$ pixel resolution. We generated a single estimate for each ecological productivity parameter (NDVI, NPP, and LST) on the seasonal and total ranges of each of the 11 subpopulations by averaging the pixel values of each parameter across the time series of the available data.

We employed the "two-step" cluster analysis method in SPSS (SPSS Inc., 2001) to create an empirical clustering of subpopulation period and amplitude using the selected variables from our regression models that significantly $(p \leq 0.05)$ increased the explanatory power $\left(\mathrm{R}^{2}\right)$ of the model. The two-step method partitions the data set into a set of "k" groups, where k represents the number of clusters. Clusters were identified by assigning subpopulation variables into one of $\mathrm{k}$ clusters by minimizing intra-cluster variation based on Euclidean distance (Norusis, 2010). The optimal number of clusters was identified based on the silhouette measure of cohesion and separation (Norusis, 2010). The silhouette measure ranges from -1 to +1 where a higher value indicates that samples are well matched to their own cluster and poorly matched to neighbouring clusters. We identified the optimal number of clusters as the fewest number of clusters that produced a silhouette value greater than 0 (Norusis, 2010).

\section{RESULTS}

Of the 14 North American subpopulations (Nagy et al., 2011; COSEWIC, 2016; Parlee et al., 2018), 11 subpopulations (George River, Leaf River, Qamanirjuaq, 
TABLE 2. We considered subpopulations sine-cyclic based on the fit $\left(\mathrm{R}^{2}\right)$ and Bayesian Information Criteria (BIC). Nine subpopulations (George River, Leaf River, Qamanirjuaq, Bathurst, Bluenose-East, Bluenose-West, Cape Bathurst, Porcupine, and Western Arctic) were classified as sine-cyclic. Estimates of period and amplitude and associated SE were reported based on the sine cycle fits to observed population abundance estimates.

\begin{tabular}{lcrrr}
\hline \hline Subpopulation & Period & SE & Amplitude & \multicolumn{1}{c}{ SE } \\
\hline George River & 51 & 2.3 & 327432 & 19936.6 \\
Leaf River & 45 & 2.0 & 298168 & 19954.7 \\
Qamanirjuaq & 54 & 4.1 & 228198 & 23735.2 \\
Bathurst & 42 & 3.4 & 203154 & 23147.1 \\
Bluenose-East & 26 & 0.1 & 71893 & 425.1 \\
Bluenose-West & 35 & 2.0 & 52408 & 3144.0 \\
Cape Bathurst & 33 & 1.5 & 8445 & 385.3 \\
Porcupine & 26 & 1.5 & 39338 & 4875.3 \\
Western Arctic & 55 & 11.1 & 219830 & 60273.1 \\
\hline \hline
\end{tabular}

Bathurst, Bluenose-East, Bluenose-West, Cape Bathurst, Porcupine, Central Arctic, Teshekpuk Lake, and Western Arctic) had sufficient subpopulation estimates (i.e., $\geq 5$ ) for a time series function analysis, and four subpopulations (Beverly, Ahiak, Dolphin-Union, and Tuktoyaktuk Peninsula) did not. The wavelet function was only fit to 6 of 11 subpopulations because of data limitations (Table 1). Cyclic (sine or wavelet) function fits to the time series subpopulation estimates were identified as the best $(\triangle \mathrm{BIC}=0)$ population projection functions for 10 of the 11 subpopulations, but $\Delta \mathrm{BIC}<2$ model selection criteria did not discriminate between most function options for the Teshekpuk Lake subpopulation (Table 1). We could not discriminate between the sine and wavelet functions for the Bathurst subpopulation (Table 1). The wavelet function was the only function to meet our validation criteria for the Central Arctic subpopulation (Table 1). The sine function with the addition of a linear increase term provided the best fit to the Porcupine time series subpopulation estimates and was the top BIC model $(\mathrm{r}=0.946, p<0.001 ; \Delta \mathrm{BIC}=$ 0; Table 1). We classified nine subpopulations-George River, Leaf River, Qamanirjuaq, Bathurst, Bluenose-East, Bluenose-West, Cape Bathurst, Porcupine (including the linear increase term) and Western Arctic as sine-cyclic (Table 1; Appendix S2). The sine function fits produced an estimate of period and amplitude for each of the nine sine-cyclic subpopulations (Table 2). The residuals for all nine sine cyclic subpopulations were normally distributed (Table 1).

We used the subpopulation period and amplitude estimates (Table 2) to calculate an expected subpopulation value that corresponded to each estimate (observed value) for all nine subpopulations (Fig. 3). The comparison of the observed and expected values for all nine sine-cyclic subpopulations produced a highly significant positive correlation (Pearson's $\mathrm{r}=0.977, p<0.001$ ), but the residuals were non-normal (S-W $(p)<0.001)$ (Fig. 3). We also used sine-cyclic subpopulation estimates of period and amplitude (Table 2 ) to project a pooled (all nine sine-cyclic

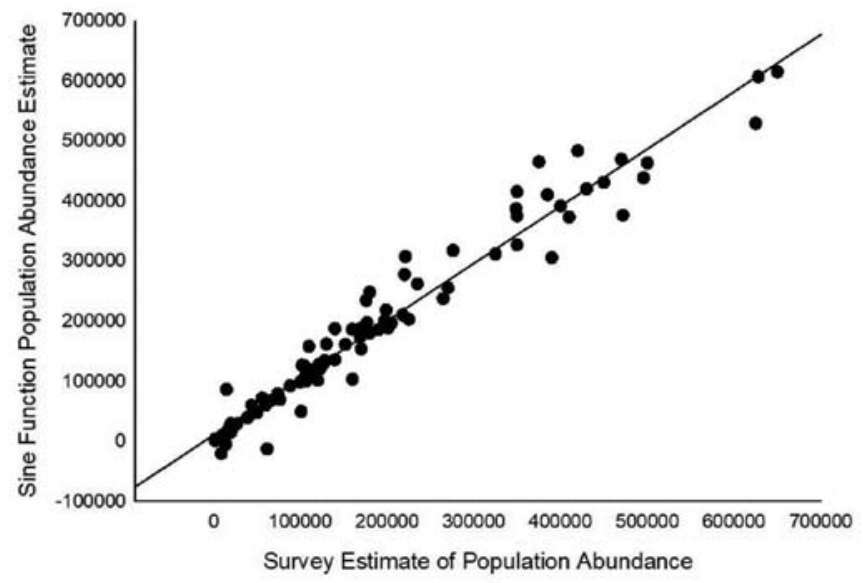

FIG. 3. We considered nine subpopulations (George River, Leaf River, Qamanirjuaq, Bathurst, Bluenose-East, Bluenose-West, Cape Bathurst, Porcupine, and Western Arctic) as sine-cyclic. We tested the sine functions correspondence by comparing the sine-generated time series estimates to the time series of subpopulation survey estimates for all nine subpopulations. The regression produced a Pearson's $r$ correlation coefficient of $r=0.977$ $(p<0.001)$, and Spearman's non-parametric correlation coefficient of $\mathrm{r}=0.978(p<0.001)$, which indicates a very strong correspondence to the sine classification

subpopulations) time series estimate (Fig. 4). Population dynamics for the nine pooled sine-cyclic barren-ground caribou subpopulations occur as resonance-damping harmonics of the individual subpopulation cycles (Fig. 4).

The correlation matrix between subpopulation seasonal range attributes and cycle characteristics identified significant $(p \leq 0.05)$ correlations between amplitude and period, NDVI, tundra percentage, total range area, summer range area, winter range area, and total range LST (Table 3). There were no individual range attributes that were significantly correlated with period, but amplitude was most highly correlated with period $(\mathrm{r}=0.822, p=0.007$; Table 3). Total range LST (a physical variable) was the best single variable predictor of subpopulation amplitude $(\mathrm{r}=0.922, p \leq 0.001$; Table 3$)$.

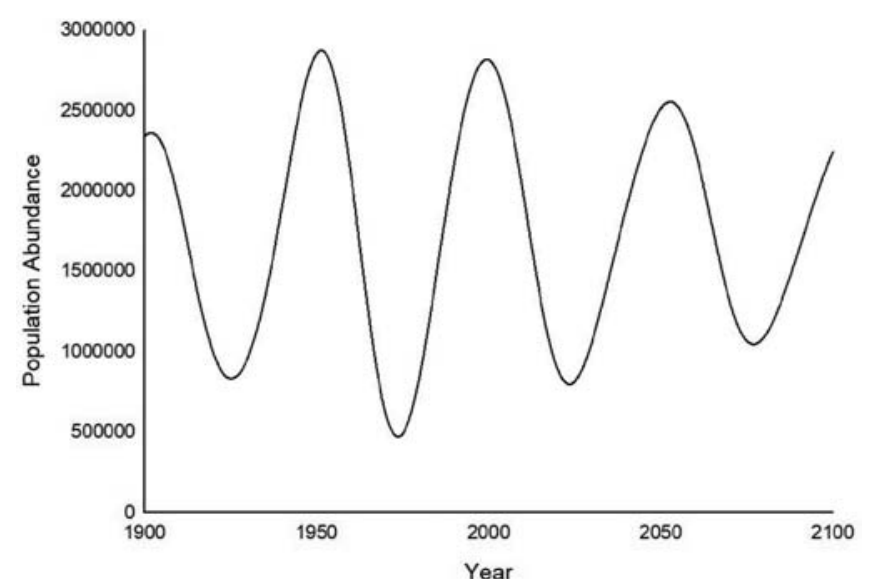

FIG. 4. We produced estimates of cycle period length and amplitude value based on the sine function fit for each of the nine subpopulations considered sine-cyclic. We extrapolated those estimates to produce a pooled population time series estimate. 


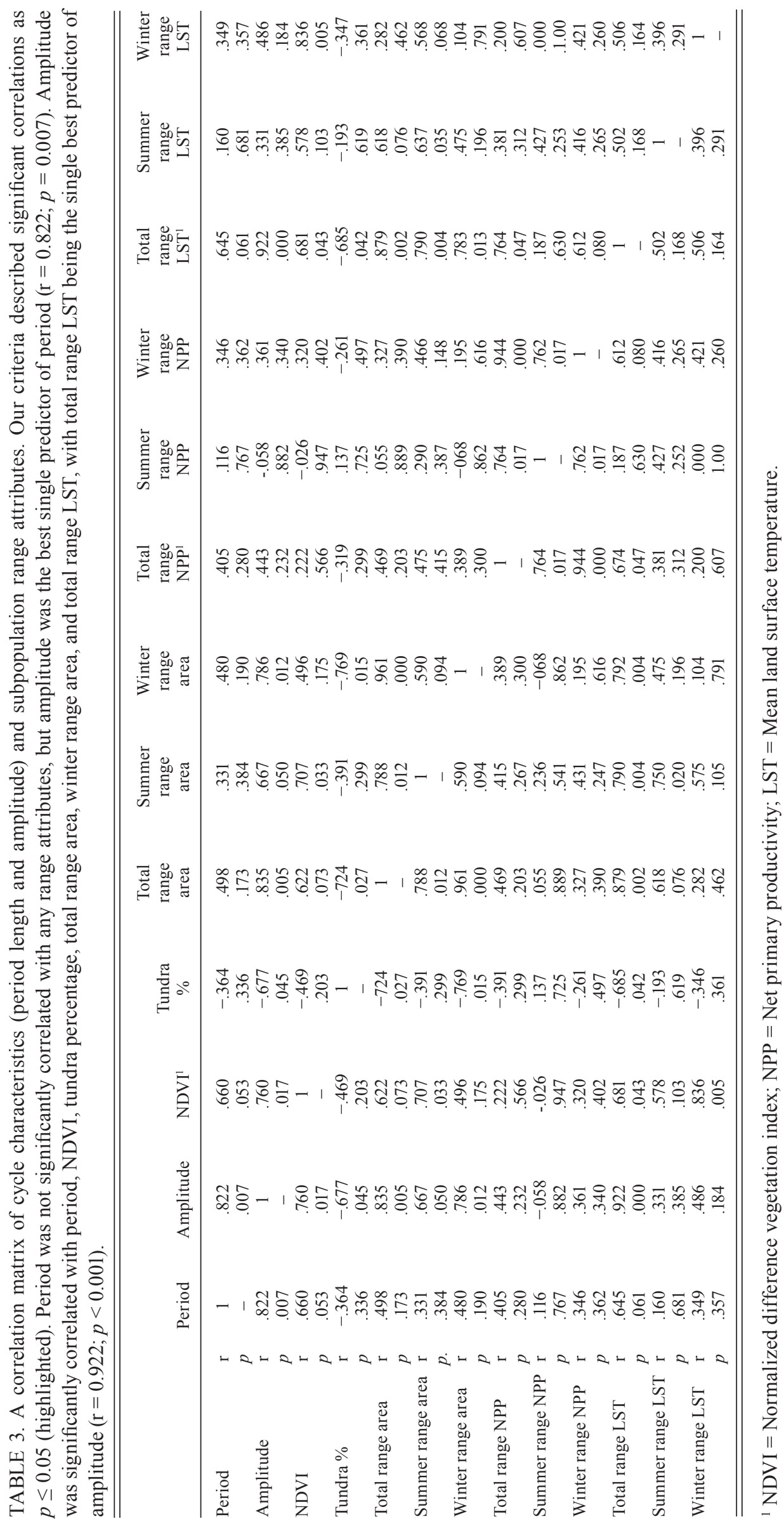


TABLE 4a. Linear regression and Bayesian Information Criteria (BIC) were employed to develop and compare models of sine-cyclic barren-ground caribou subpopulation amplitude as functions of environmental and biological range variables. Statistically significant $(p \leq 0.05)$ models with $\Delta$ BIC values $<2.0$ (bolded) were regarded as equivalent. Three models (model \#5, \#9, and \#13) met our required criteria. Model \#5 was selected because it was the best model $(\Delta \mathrm{BIC}=0)$ and explained the greatest percentage of variation $\left(\mathrm{R}^{2}=0.962\right)$.

Model 13 produced an equivalent value of $\mathrm{R}^{2}$, however it contained one additional variable.

\begin{tabular}{|c|c|c|c|c|}
\hline Model \# & Parameters $^{1}$ & RSS & $\mathrm{R}^{2}$ & $\Delta \mathrm{BIC}$ \\
\hline 1 & Total range area & $3.41 \mathrm{E}+10$ & $0.694(0.005)$ & 5.270 \\
\hline 2 & Total range area, summer range area & $3.41 \mathrm{E}+10$ & $0.694(0.029)$ & 6.224 \\
\hline 3 & Total range area, summer range NPP & $3.28 \mathrm{E}+10$ & $0.706(0.025)$ & 6.073 \\
\hline 4 & Total range area, summer range area, summer range NPP & $3.25 \mathrm{E}+10$ & $0.708(0.083)$ & 6.999 \\
\hline 5 & Total range area, summer range area, summer range NPP, summer range area $\times$ summer range NPP & $4.25 \mathrm{E}+09$ & $0.962(0.004)$ & 0.000 \\
\hline 6 & Total range area, summer range area $\times$ summer range NPP & $3.34 \mathrm{E}+10$ & $0.701(0.027)$ & 6.142 \\
\hline 7 & Total range mean LST, summer range area & $1.60 \mathrm{E}+10$ & $0.857(0.003)$ & 3.258 \\
\hline 8 & Total range LST, summer range area, tundra percentage & $1.59 \mathrm{E}+10$ & $0.858(0.015)$ & 4.187 \\
\hline 9 & Total range LST, summer range NPP & $1.08 \mathrm{E}+10$ & $0.903(0.001)$ & 1.737 \\
\hline 10 & Total range LST, winter range area & $1.59 \mathrm{E}+10$ & $0.857(0.003)$ & 3.253 \\
\hline 11 & Total range area, winter range NPP & $3.31 \mathrm{E}+10$ & $0.703(0.026)$ & 6.113 \\
\hline 12 & Total range area, total range NPP & $3.37 \mathrm{E}+10$ & $0.697(0.005)$ & 6.186 \\
\hline 13 & $\begin{array}{l}\text { Total range area, summer range area, summer range NPP, summer range area } \times \text { summer range NPP, } \\
\text { total range LST }\end{array}$ & 4.23E+09 & $0.962(0.024)$ & 0.930 \\
\hline 14 & Summer range area, summer range LST & $5.50 \mathrm{E}+10$ & $0.507(0.120)$ & 8.097 \\
\hline 15 & Total range area, summer range area, summer range LST & $2.45 \mathrm{E}+10$ & $0.780(0.042)$ & 5.896 \\
\hline 16 & Total range area, winter range area, winter range NPP, winter range area $\times$ winter range NPP & $3.16 \mathrm{E}+10$ & $0.716(0.196)$ & 7.842 \\
\hline 17 & Total range area, total range NPP, total range area $\times$ total range NPP & $3.08 \mathrm{E}+10$ & $0.724(0.073)$ & 6.780 \\
\hline 18 & $\begin{array}{l}\text { Summer range area } \times \text { summer range NPP, winter range area } \times \text { winter range NPP, } \\
\text { total range area } \times \text { total range NPP }\end{array}$ & $3.21 \mathrm{E}+10$ & $0.713(0.080)$ & 6.939 \\
\hline 19 & Winter range area, winter range NPP, winter range area $\times$ winter range NPP & $3.67 \mathrm{E}+10$ & $0.671(0.111)$ & 7.472 \\
\hline 20 & Total range LST, winter range area, winter range NPP, winter range area $\times$ winter range NPP & $9.55 \mathrm{E}+09$ & $0.914(0.021)$ & 3.161 \\
\hline 21 & Total range LST, total range area $\times$ total range NPP & $1.72 \mathrm{E}+10$ & $0.846(0.004)$ & 3.543 \\
\hline 22 & Total Range Area, Total Range LST & $1.69 \mathrm{E}+10$ & $0.849(0.003)$ & 3.474 \\
\hline 23 & Total range area, total range LST, summer range area $\times$ summer range NPP & $1.24 \mathrm{E}+10$ & $0.889(0.008)$ & 3.225 \\
\hline 24 & Total range area, summer range LST, summer range area $\times$ summer range NPP & $2.65 \mathrm{E}+10$ & $0.762(0.051)$ & 6.202 \\
\hline
\end{tabular}

Three of the amplitude environmental regression models were indistinguishable at $\Delta \mathrm{BIC}<2$ (Table 4a). Our preferred environmental regression model for amplitude was model $\# 5\left(\mathrm{R}^{2}=0.962, p<0.007 ; \Delta \mathrm{BIC}=0\right.$; Table 4a, Fig. 5). The model included total range area, summer range area, summer range NPP, and the interaction of summer range area $\times$ summer range NPP. Summer range area and summer range NPP as main effects contributed little to the final amplitude model but were necessary to include because the interaction effect (summer range area $\times$ summer range NPP) did significantly improve the model ( $p=0.007$; Table 4b). Comparison of sine function estimates of subpopulation amplitude and environmental regression model estimates of subpopulation amplitude produced a Pearson's correlation coefficient of $\mathrm{r}=0.981$ $(p<0.001$, S-W $(p)=0.518$; Fig. 5).

Three of the period environmental regression models were indistinguishable at $\Delta \mathrm{BIC}<2$ (Table 5a). Our preferred environmental regression model for period was model \# $25\left(\mathrm{R}^{2}=0.950, p<0.007 ; \Delta \mathrm{BIC}=0\right.$; Table 5a, b; Fig. 6). All three BIC $<2$ models included a similar combination of environmental variables: amplitude, total range area, total range productivity (i.e., total range NPP or total range area $\times$ total range NPP), and total range LST (Table 5a). Model \#25 was intermediate with respect to parameter count and the best $(\Delta \mathrm{BIC}=0)$ model. Comparison of sine function estimates of period and environmental regression model estimates of

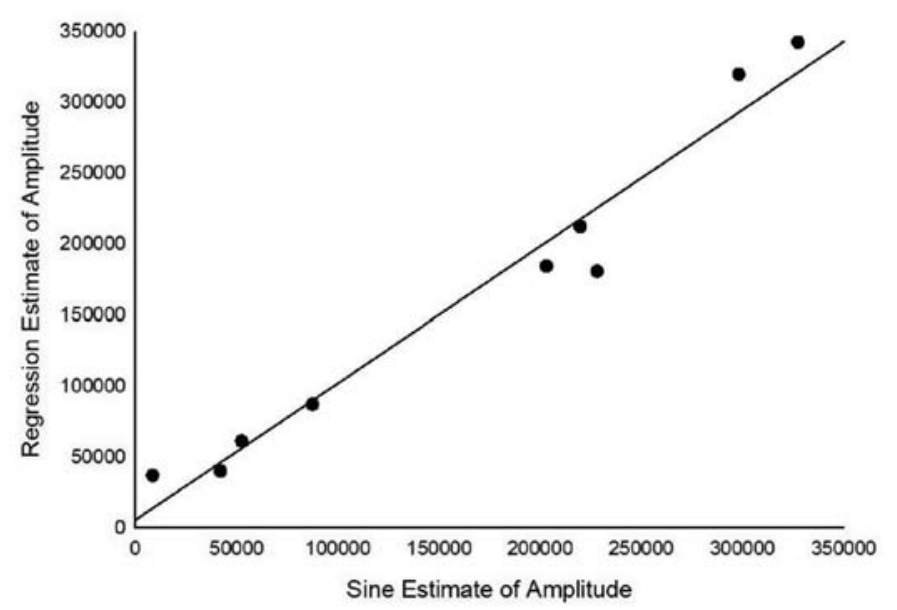

FIG. 5. The best multiple linear regression model $(\triangle \mathrm{BIC}=0)$ for amplitude explained approximately $96 \%(p=0.004)$ of the variation and included total range area, summer range area, summer range NPP, and the interaction of summer range area $\times$ summer range NPP. Summer range area and summer range NPP were only included in the model because the interaction effect (summer range area $\times$ summer range NPP) was significant. A comparison of regression model estimates of amplitude and sine function estimates of amplitude produced a correlation coefficient of $r=0.981(p=0.004)$.

subpopulation period produced a correlation coefficient of $\mathrm{r}=0.975(p<0.001$, S-W $(p)=0.132$; Fig. 6).

The estimates of period and amplitude from the environmental regression models allowed extrapolation of "predicted" individual subpopulation time series values. Comparison of the extrapolated subpopulation numbers 


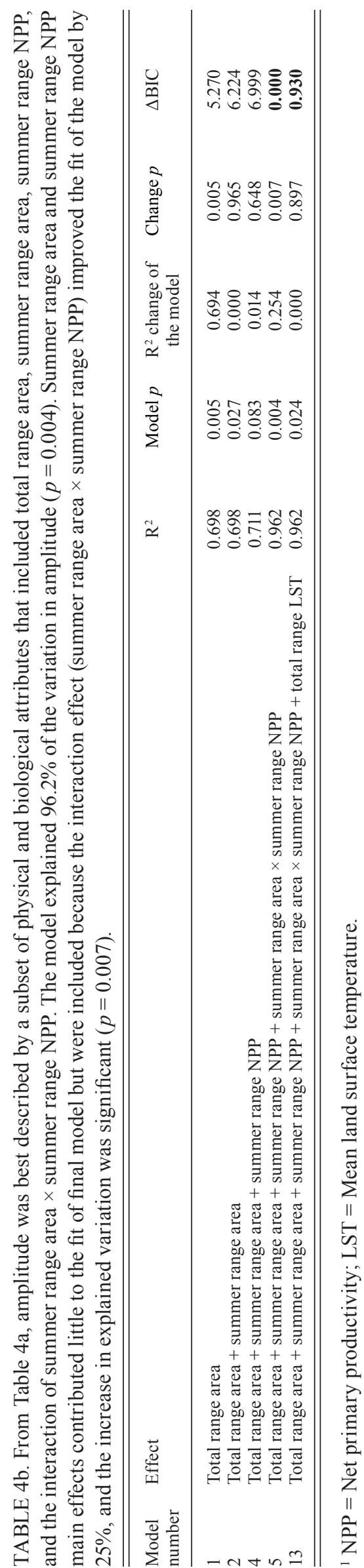

from the preferred environmental models to the observed subpopulation estimates $(\mathrm{n}=91)$ produced a significant positive correlation with symmetrical residuals $(\mathrm{r}=0.964$, $p<0.001, \mathrm{~S}-\mathrm{W}(p)=0.430)$ for the set of nine sine-cyclic subpopulations (Fig. 7).

Amplitude cluster analysis was based on total range area and the interaction of summer range area $\times$ summer range NPP. The optimal number of clusters identified was two (silhouette measure $=0.7$ ). Cluster one (i.e., George River, Leaf River, and Porcupine) was characterized by larger total areas and higher values of summer range area $\times$ summer range NPP (Fig. 8). Cluster two (i.e., Qamanirjuaq, Bathurst, Bluenose-East, Bluenose-West, Cape Bathurst, and Western Arctic) was characterized by smaller total range areas and lower values of summer range area $x$ summer range NPP (Table 6, Fig. 9).

The period cluster analysis was based on amplitude and total range LST. The optimal number of clusters was two (silhouette measure $=0.7$ ). Cluster one (i.e., George River, Leaf River, Qamanirjuaq, Bathurst and Western Arctic) was characterized by larger amplitude values and warmer total range mean temperatures (Table 6, Fig. 9). Cluster two (i.e., Bluenose-East, Bluenose-West, Cape Bathurst and Porcupine) was characterized by smaller amplitude values and cooler total range mean temperatures (Fig. 9).

\section{DISCUSSION}

Of the 14 barren-ground subpopulations (Nagy et al., 2011; COSEWIC, 2016; Parlee et al., 2018), four subpopulations (Beverly, Ahiak, Dolphin-Union, and Tuktoyaktuk Peninsula) had insufficient population estimates to allow comparison of population dynamics functions. Of the 11 remaining barren-ground subpopulations, we were unable to classify two (Teshekpuk and Central Arctic) as sine-cyclic based on BIC criteria (Table 1). BIC identified the remaining nine barren-ground subpopulations (George River, Leaf River, Qamanirjuaq, Bathurst, Bluenose-East, Bluenose-West, Cape Bathurst, Porcupine, and Western Arctic) as sine-cyclic.

The wavelet function was the only function to produce $\Delta \mathrm{BIC}<2.0$ to the Central Arctic time series subpopulation estimates. The wavelet estimate of cycle period length and amplitude value converges on a sine cycle estimate of period length and amplitude value when a true sine curve is sampled symmetrically for at least one complete cycle $(\mathrm{r}=1.0, p<0.001$; Fig. 1). However, the converse is not always true because the wavelet function can fit time series data that comprise multiple simultaneous cycles (Zhang et al., 2000). We rejected the Central Arctic subpopulation as sine-cyclic, while noting that the wavelet function was the best model $(\triangle \mathrm{BIC}=0$; Table 1$)$.

The Porcupine subpopulation sine function fit to the observed time series population estimates was improved by the addition of a linear increase term (Table 1). The sine function that included the additional linear term was 
TABLE 5a. Linear regression and Bayesian Information Criteria (BIC) were employed to develop and compare models of sine-cyclic barren-ground caribou subpopulation period as functions of environmental and biological range variables. Statistically significant $(p \leq 0.05)$ models with $\triangle \mathrm{BIC}$ values $<2.0$ (bolded) were regarded as equivalent. Three models (model \#23, \#24, and \#25) met our required criteria. Model 25 was selected because it was the best model $(\Delta \mathrm{BIC}=0)$ and explained $95.0 \%$ of the variation in period $(p=0.007)$.

\begin{tabular}{|c|c|c|c|c|}
\hline Model \# & Parameters $^{1}$ & RSS & $\mathrm{R}^{2}$ & $\Delta \mathrm{BIC}$ \\
\hline 1 & Amplitude & 339.27 & $0.678(0.000)$ & 4.425 \\
\hline 2 & Amplitude, total range area & 217.33 & $0.794(0.009)$ & 3.638 \\
\hline 3 & Total range area, summer range NPP & 783.67 & $0.256(0.412)$ & 8.651 \\
\hline 4 & Total range area, winter range NPP & 752.48 & $0.285(0.365)$ & 8.492 \\
\hline 5 & Total range area, tundra percentage & 791.89 & $0.248(0.425)$ & 8.692 \\
\hline 6 & Amplitude, total range LST & 253.37 & $0.759(0.014)$ & 4.238 \\
\hline 7 & Total range LST, total range area & 592.36 & $0.437(0.178)$ & 7.557 \\
\hline 8 & Amplitude, total range area, total range LST & 200.16 & $0.810(0.030)$ & 4.271 \\
\hline 9 & Amplitude, total range area, total range area $\times$ total range NPP & 174.29 & $0.834(0.021)$ & 3.730 \\
\hline 10 & Amplitude, total range area, total range LST, tundra percentage & 180.23 & $0.829(0.078)$ & 4.815 \\
\hline 11 & Amplitude, tundra percentage & 266.71 & $0.747(0.016)$ & 4.438 \\
\hline 12 & Total range area, total range LST, tundra percentage & 588.48 & $0.441(0.367)$ & 8.486 \\
\hline 13 & NDVI, total range area & 580.75 & $0.448(0.168)$ & 7.480 \\
\hline 14 & Amplitude, summer range area & 252.45 & 0.760() $.014)$ & 4.224 \\
\hline 15 & Amplitude, winter range area & 263.33 & $0.750(0.016)$ & 4.388 \\
\hline 16 & Amplitude, summer range area $\times$ summer range NPP & 286.57 & $0.728(0.020)$ & 4.719 \\
\hline 17 & Amplitude, summer range area, summer range NPP & 160.80 & $0.847(0.018)$ & 3.415 \\
\hline 18 & Amplitude, summer range area, summer range NPP, summer range area $\times$ summer range NPP & 145.70 & $0.862(0.052)$ & 3.984 \\
\hline 19 & Total range area, summer range area, summer range NPP, summer range area $\times$ summer range NPP & 247.37 & $0.765(0.140)$ & 6.053 \\
\hline 20 & Total range LST, winter range area, winter range NPP, winter range area $\times$ winter range NPP & 560.91 & $0.467(0.549)$ & 9.252 \\
\hline 21 & Amplitude, total range area $\times$ total range NPP & 253.89 & $0.759(0.014)$ & 4.246 \\
\hline 22 & Amplitude, total range area, total range NPP, total range area $\times$ total range NPP & 157.04 & $0.851(0.060)$ & 4.277 \\
\hline 23 & Amplitude, total range area, total range area $\times$ total range NPP, total range LST, total range NPP & 43.63 & $0.959(0.028)$ & 0.225 \\
\hline 24 & Amplitude, total range area, total range NPP, total range LST & 67.784 & $0.936(0.012)$ & 0.993 \\
\hline 25 & Amplitude, total range area, total range area $\times$ total range NPP, total range LST & 52.58 & $0.950(0.007)$ & 0.000 \\
\hline 26 & Amplitude, total range area $\times$ total range NPP, total range LST & 234.32 & $0.777(0.044)$ & 4.886 \\
\hline
\end{tabular}

the only function selected using model selection criteria $(\triangle \mathrm{BIC} \leq 2)$ and fit $\left(\mathrm{R}^{2}\right)$ (Table 1$)$. Annual increases in abundance and sine-cyclic fluctuations in numbers could be due to increases in annual net productivity induced by climate warming across the Porcupine range, immigration from adjacent subpopulations, or increased selection for males in the harvest beginning in 2010 (T. Hegel, pers. comm. 2018). The Porcupine, Central Arctic, and Teshekpuk Lake subpopulations are all found in Alaska and all of their ranges overlap (ADFG, 2017) (Fig. 10). The Alaska Department of Fish and Game (2017) reported that approximately $18 \%$ of collared caribou migrated from the Central Arctic subpopulation to either the Teshekpuk Lake or Porcupine subpopulations prior to the 2016 photocensus, which suggests that these subpopulations are not demographically robust. The unmodified sine function was not ranked as the best population dynamics model for the Porcupine, Teshekpuk Lake, or Central Arctic subpopulations. However, the sine-cyclic function was identified as the best model for the adjacent Western Arctic subpopulation $\left(\triangle \mathrm{BIC}=0 ; \mathrm{R}^{2}=0.972\right.$; Table 1$)$. The Western Arctic barren-ground caribou subpopulation appears to be demographically distinct from the other three Alaskan subpopulations, which appear to be demographically linked. Subpopulation fidelity (effective demographic closure) is required to establish and maintain a given sinecycle time series.

Both $\mathrm{BIC}$ and fit $\left(\mathrm{R}^{2}\right)$ indicated approximately equal support for the wavelet and sine function fits to the Bathurst subpopulation time series subpopulation estimates. We classified the Bathurst subpopulation as sine-cyclic to retain consistency with other sine-cyclic subpopulations in our analysis. The Bathurst subpopulation had the lowest fit $\left(\mathrm{R}^{2}=0.874\right)$ of any of the nine sine-cyclic subpopulations (Table 1) and the residuals were symmetrical $(\mathrm{S}-\mathrm{W}(p)=$ 0.316). The sine-cyclic fit to the Bathurst subpopulation time series suggests that its abundance should currently be increasing, however, the most recent estimate indicates that the expected increase in the Bathurst subpopulation is not occurring (Appendix S1). The Northwest Territories believes that wolf predation could be preventing recovery from current low numbers (WRRB, 2019). Others suggest that the recovery of the Bathurst subpopulation might also be delayed due to recent increases in anthropogenic disturbance (Boulanger et al., 2012; Adamczewski et al., 2013; COSEWIC, 2016). The strong correspondence of the Bathurst subpopulation abundance estimates to the sine cycle (Table 1) suggests historical resilience of the subpopulation cycle to both natural and anthropogenic disturbance. The symmetrical distribution of variance associated with the Bathurst sine cycle is inconsistent with a history of unmitigated progressive disturbance such as incremental development or climate warming. An alternative explanation for the apparent delay in Bathurst subpopulation increase is short-term emigration of some Bathurst individuals to the three adjacent subpopulations (Bluenose East, Beverly, and Qamanirjuaq) that collectively overlap most of the Bathurst subpopulation's range (Nagy et al., 2011; COSEWIC, 2016; McFarlane et al., 2016) (Fig. 10). Adamczewski et al. (2019) noted that about $27 \%$ 
of the Bathurst subpopulation cows may have emigrated and joined the Beverly subpopulation (which outnumbered the Bathurst subpopulation 12:1) on the shared winter range in spring of 2017. Additionally, the difference between the most recent Bathurst subpopulation estimate and the expected (sine-cyclic) extrapolated number $(\Delta \mathrm{N}=9164)$ was numerically small relative to the uncertainty inherent in both modeling and subpopulation estimation variance. These various hypotheses are not mutually exclusive, and our data are insufficient to resolve them.

The sine cycle function is a symmetrical repeating time series function if there are no perturbations to disturb it. BIC model selection for sine-cyclic subpopulation dynamics with high associated R2 values (range: $0.874-0.999$, mean $=0.948$; Table 1 ) and normal residuals (S-W $(p)$ range: $0.950-0.051$; Table 1$)$ is evidence that sinecyclic subpopulations are demographically distinct. These results are consistent with robust clustering of individuals into the same barren-ground caribou subpopulations based on radio-collared caribou movements (Nagy et al., 2011). Identification of the sine-cyclic model as the most correct model for demographically distinct subpopulations implies that subpopulation period and amplitude have remained relatively constant through the time period $(1958-2017)$ in which these population estimates were developed. We tested the sine-cyclic function's overall correspondence to nature by comparing the sine-generated time series estimates to the time series of observed subpopulation estimates for all nine subpopulations (Fig. 3). That regression produced a Pearson correlation coefficient of $\mathrm{r}=0.977(p<0.001)$ with non-normal residuals (S-W $(p)<0.001)$. Spearman's nonparametric correlation coefficient was similar $(r=0.978)$, confirming good overall correspondence of the sine cycle function to the subpopulation estimates considered as a whole.

None of the individual sine cycle fits exhibit non-normal residuals, but the pooled residuals for all nine sine-cyclic subpopulations tested non-normal ( $\mathrm{S}-\mathrm{W}(p)<0.001)$. One possibility is that the power of tests for normality is highly dependent on sample size (Yap and Sim, 2011). The power of the Shapiro-Wilk tests for individual subpopulations was 7 to 10 times less powerful than the same test for nine pooled subpopulations $(\mathrm{n}=91)$. Alternatively, the pooled subpopulation regression may have mixed subpopulation residuals with different variances due to individual differences in subpopulation period and amplitude.

We assumed that the subpopulation estimates developed by many different research programs over a span of approximately 58 years were reliable and sound. We received several review comments that questioned this assumption. Our response is that BIC selection of the sine cycle as the correct model is conservative, and the fit (lowest sine-cyclic subpopulation $\mathrm{R}^{2}=0.874$; Table 1) suggests that the various subpopulation estimates were generally accurate and consistent over this time span.

Given that the observed cycles cannot be birthpulse stable limit cycles, the causes for barren-ground 


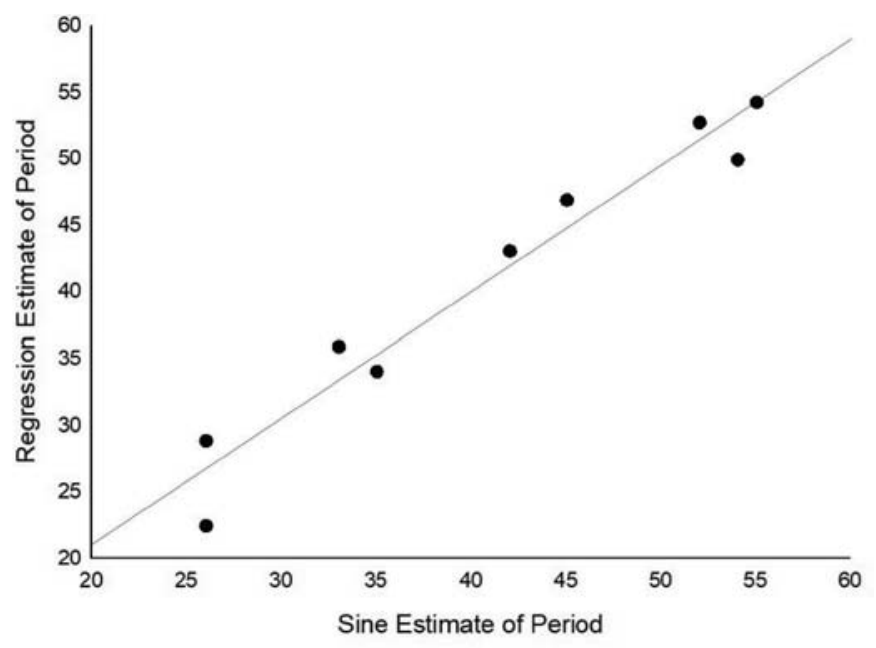

FIG. 6. The best multiple linear regression model $(\Delta \mathrm{BIC}=0)$ for period explained approximately $95 \%(p=0.007)$ of the variation and included amplitude, total range area, the interaction of total range area $\times$ total range NPP and total range LST. Total range area and the interaction between total range area and total range NPP contributed little to the final model as main effects but were included because the whole model was significant with the stepwise addition of each parameter. A comparison of regression model estimates for period and sine function estimates of period produced a correlation coefficient of $\mathrm{r}=0.975(p=0.007)$.

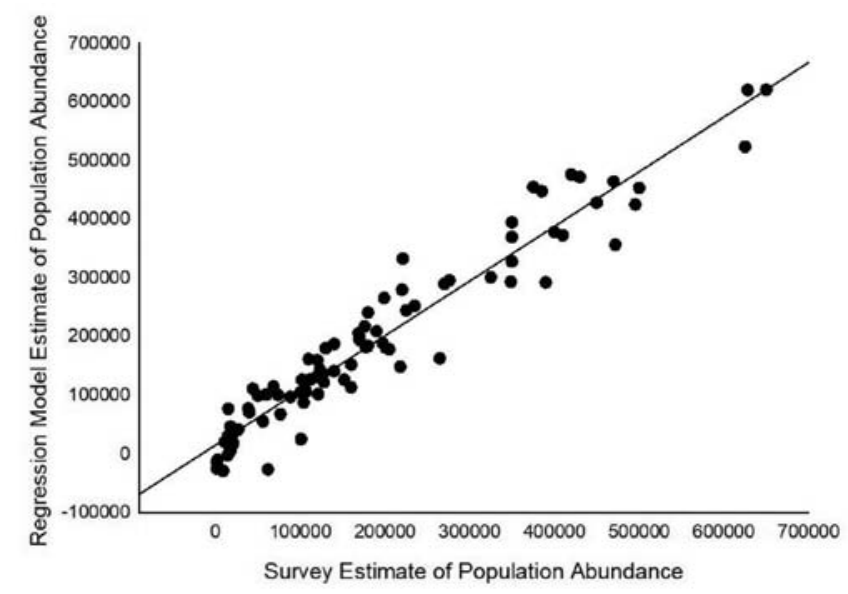

FIG. 7. We extrapolated the regression estimates of subpopulation period and amplitude to produce individual time series population estimates. Comparison of the subpopulation numbers extrapolated from the environmental models to the observed subpopulation estimates produced a significant positive correlation $(\mathrm{r}=0.964, p<0.001, \mathrm{~S}-\mathrm{W}(p)=0.430)$.

caribou sine cycles in pristine regions must be found in the ecological relationships of their trophic system, environmental constraints, seasonality of their range, and the annual migrations. Historically, North American barren-ground caribou appear to have cycled up and down to unchanging subpopulation-specific rhythms that are decades long and apparently resilient to the suite of factors currently identified as threats to their continued persistence.

Each of the sine-cyclic subpopulations had unique period and amplitude values (Table 2), which formed a general NW-SE gradient of increasing cycle period length and amplitude value. This trend was unexpected given the SW-NE gradient of decreasing NPP running

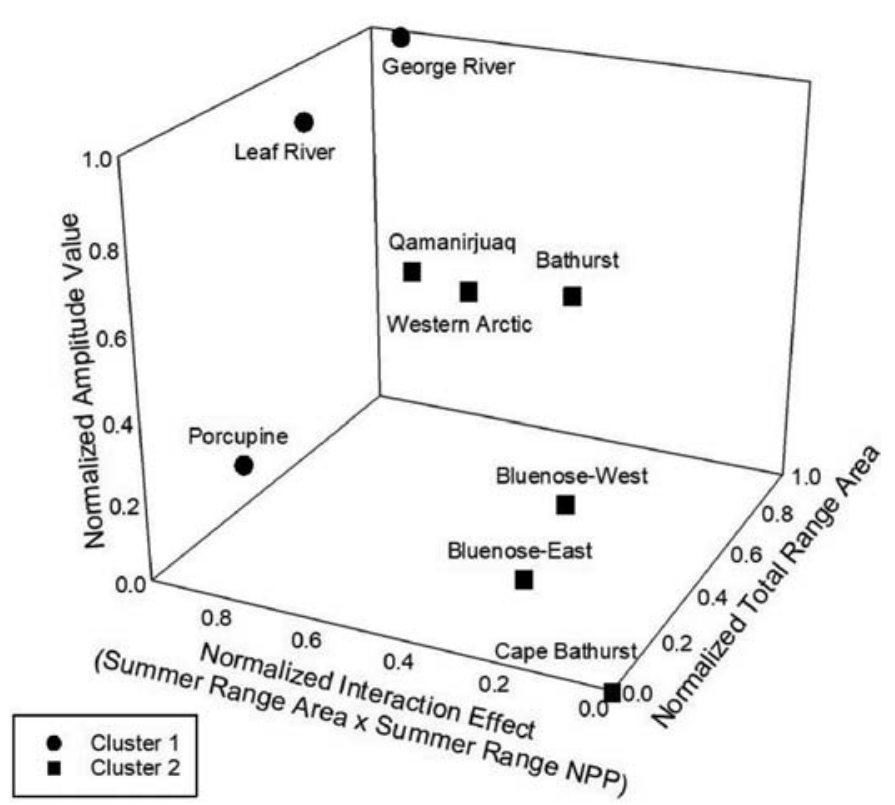

FIG. 8. We created an empirical clustering of subpopulation amplitude using the variables from our amplitude regression model that significantly $(p \leq 0.05)$ increased the explanatory power $\left(\mathrm{R}^{2}\right)$ of the model (total range area and the interaction of summer range area $\times$ summer range NPP). The optimal number of clusters based on the silhouette measure of cohesion was two. We normalized and plotted the values against amplitude to illustrate the distribution of clusters. Cluster 1 (George River, Leaf River, and Porcupine) was characterized by larger total range areas and high values of summer range area $\times$ summer range NPP. Cluster 2 (Qamanirjuaq, Bathurst, Bluenose-East, Bluenose-West, Cape Bathurst, and Western Arctic) was characterized by smaller total range areas and lower values of summer range area $\times$ summer range NPP.

perpendicular to the treeline. Subpopulations with ranges in close proximity to coastal regions (e.g., Western Arctic, Qaminirjuaq, and George River) had longer periods and greater amplitudes than more continental subpopulations (e.g., Bluenose-East, Bluenose-West, and Cape Bathurst) (Table 2).

Our best environmental regression model for amplitude (Model 5, $\mathrm{R}^{2}=0.962, p \leq 0.001 ; \Delta \mathrm{BIC}=0$ ) suggests that subpopulation amplitude is mainly determined by total range area and summer range productivity (summer range area $\times$ summer range NPP). Models 9 and 13 also had associated $\triangle \mathrm{BIC}<2.0$. (Table $4 \mathrm{a}, \mathrm{b}$ ). Model 9 was only able to explain $90 \%$ of the variation in amplitude (Table 4a). Model 13 was able to explain an equal $(96.2 \%)$ amount of variation in amplitude compared to the selected model, but the additional parameter (total range LST) did not significantly improve the explanatory power (fit) of the model (Table $4 \mathrm{a}, \mathrm{b})$.

Three of the 26 environmental regression models for period had associated $\triangle \mathrm{BIC} \leq 2$ (Tables $5 \mathrm{a}, \mathrm{b}$ ). All three models contained amplitude, total range area, total range NPP, and total range LST (Tables 5a, b). We selected Model $25\left(\mathrm{R}^{2}=0.950, \mathrm{p} \leq 0.007, \mathrm{BIC}=0\right)$ as the best model based on BIC, parsimony, and intermediate in fit compared to the other two BIC $<2$ models (Tables 5a, b). Period was most correlated to amplitude ( $\mathrm{r}=0.822, p \leq 0.007$; Table 3 ), presumably because the time required for a subpopulation 


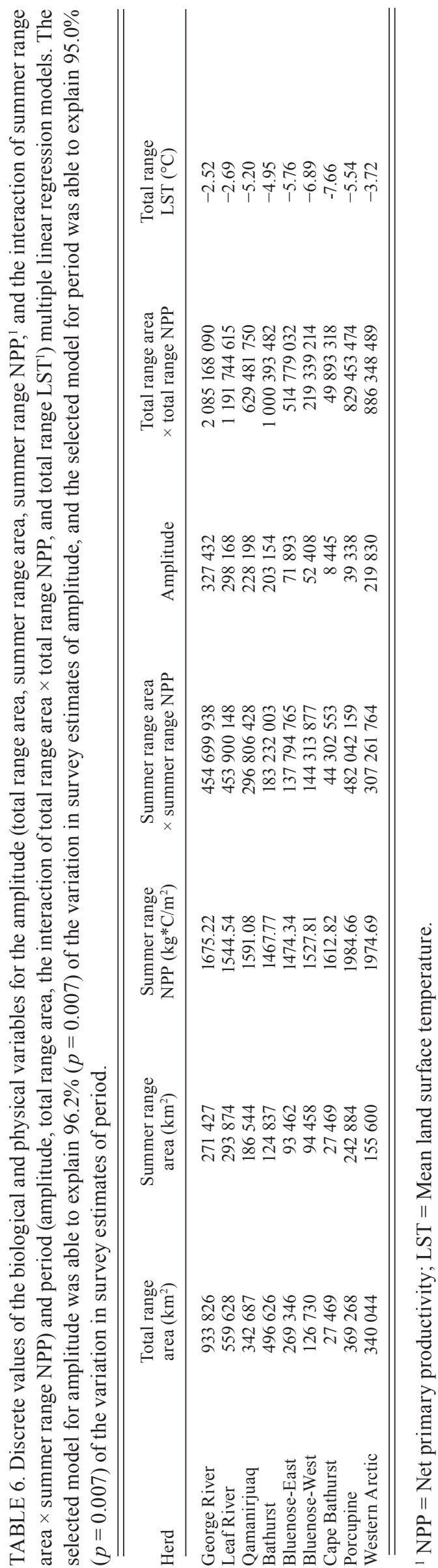

to increase and decline is longer for large amplitudes compared to small amplitudes. All environmental regression coefficients were positive, so increased total range size and increased net primary productivity would increase the estimate of period. One interpretation is that a larger and warmer total range with greater ecological productivity would allow for a larger subpopulation, which in turn, requires a longer time period (more generations) to complete the cycle.

In general terms, both amplitude and period models suggest that barren-ground caribou cycle characteristics are mainly determined by the size and productivity of their range. For amplitude, it appears that summer range size and productivity is of particular importance. For period, both summer and winter range productivity are important because the period model contains both amplitude (function of summer range productivity) and total range productivity. We tested the environmental regression models correspondence to nature by first estimating and then comparing the amplitude $(\mathrm{r}=0.981 ; p<0.001$; Fig. 5) and period $(\mathrm{r}=0.975 ; p<0.001 ;$ Fig. 6$)$ regression estimates to sine cycle estimates of amplitude and period for each of the nine sine-cyclic subpopulations. Next, we compared the environmental regression models extrapolated time series of subpopulation numbers to the actual subpopulation estimates for all nine sine-cyclic subpopulations pooled $(\mathrm{r}=0.964 ; p<0.001, \mathrm{~S}-\mathrm{W}(p)=0.430$; Fig. 7). When the environmental determinants of subpopulation period and amplitude were considered (i.e., the environmental regression model), the residuals from the predicted number versus actual subpopulation estimates were normally distributed.

The true test of any model is how well it predicts the future, not how well it fits the past. Considering that subpopulation boundaries were based on telemetry analysis of movements and fidelity to calving grounds and that the time series of subpopulation numbers in our sample was developed over a 59-year time span employing different methodologies in different regions with different harvest regimes and different levels of development, it is remarkable that $96 \%$ of the variability in these demographic data (Fig. 7) could be reliably explained from period and amplitude estimates derived from remotely sensed largescale environmental indices. The good correspondence of simple environmental models for period and amplitude to nature demonstrates constancy of the sine cycle throughout the sampling period. These results suggest that from 1958 to 2017 barren-ground caribou cycles were not strongly influenced by short-term subpopulation specific circumstances such as development, decadal weather events, insect harassment, harvest levels, wolf predation, disease, or contaminants or large-scale progressive perturbations such as climate change. What does appear to have caused some subpopulations of barren-ground caribou to deviate from sine cycle subpopulation dynamics is migration between subpopulations, particularly when the range conditions may be poor during the cyclic lows. 


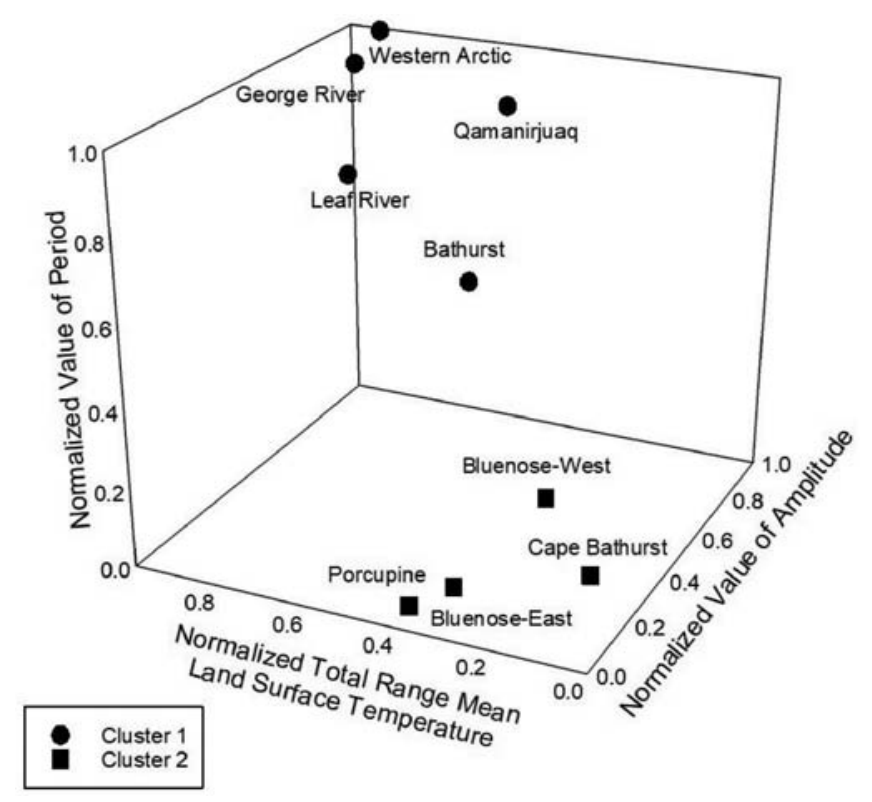

FIG. 9. We created an empirical clustering of subpopulation period using the variables from our period regression model that significantly $(p \leq 0.05)$ increased the explanatory power $\left(\mathrm{R}^{2}\right)$ of the model (amplitude and total range LST). The optimal number of clusters based on the silhouette measure of cohesion was two. We normalized and plotted the values against period to illustrate the distribution of clusters. Cluster 1 (George River, Leaf River, Qamanirjuaq, Bathurst, and Western Arctic) was characterized by longer period lengths, larger total range area, and warmer total range mean land surface temperatures. Cluster 2 (Bluenose-East, Bluenose-West, Cape Bathurst, and Porcupine) was characterized by shorter period lengths, smaller amplitude values, and cooler total range mean land surface temperatures.

Many researchers (e.g., Klein, 1970, 1986; Manseau et al., 1996; Parker et al., 2005) have suggested that the quality and volume of forage availability on the seasonal ranges of barren-ground caribou subpopulations drive population cycling. Our regression model suggested that total range area, summer range area, summer range NPP, and the interaction between summer range area $\times$ summer range NPP were sufficient to explain $96.2 \%(p<0.001)$ of the variation in amplitude (Table 4a, b; Fig. 5). Amplitude, total range area, the interaction of total range area $\times$ total range NPP, and total range LST were sufficient to explain $95 \%$ $(p<0.001)$ (Table 5a, b; Fig. 6) of the variation in period for the subpopulations we classified as sine-cyclic. Our results support the Gunn (2003) hypothesis that slow recovery of vegetation from over-grazing drives barren-ground caribou subpopulation cycling. Range size and ecological productivity determine the characteristics of barren-ground caribou cycles by setting the upper limits to amplitude and period and also by determining habitat recovery times through forage regeneration rates. This result can be viewed in the comparative context provided by cluster analyses (Figs. 8, 9). Subpopulations with a larger seasonal range and higher values of ecological productivity (i.e., summer range area $\times$ summer range NPP) tended to have larger amplitude values (Fig. 8). Subpopulations characterized by warmer total rangeland surface temperature and larger amplitude values tend to have longer periods (Fig. 9).
Fauchald et al. (2017) suggest that local or regional climatic trends could influence subpopulation cycle characteristics. Progressive climate change could alter forage selection and availability, calving ground preference, biome type, range boundaries, productivity, and habitat recovery times. Our environmental regression models suggest that progressively longer growing seasons and increased productivity would cause a shift to larger amplitudes with longer cycle periods. The maximum and minimum rates of population growth (or decline) for barren-ground caribou vary between subpopulations but typically do not exceed $\lambda=1.17$ and are not less than $\lambda=0.83$ (Gunn, 2003). Given these constraints, subpopulations with larger, more productive range areas require more time for the subpopulation to increase to levels where density effects reduce vital rates and cause the subpopulation to decline. Similarly, for larger subpopulations, declines and recoveries take longer to occur, perhaps delaying vegetation recovery by extending the over-grazing period (Mysterud, 2006). However, the high correlation of the sine cycle (constant period and amplitude) to the time series of sine-cyclic subpopulation estimates suggests that climate warming has had a negligible effect on barren-ground caribou subpopulation cycles thus far within the subpopulations we studied.

Several barren-ground caribou subpopulations have experienced declines in abundance over approximately the last two decades (Gunn et al., 2010; CARMA, 2016; COSEWIC, 2016). Both COSEWIC and the IUCN have responded to the declines in subpopulation abundance by designating barren-ground caribou species as "threatened" and "vulnerable," respectively. COSEWIC and the IUCN determine status based on trends in population abundance over a three-generation period and use a threshold of a $50 \%$ or greater reduction in total mature individuals (when the causes of the decline are known, understood, and reversible) as one of the criteria for threatened or vulnerable species designations (COSEWIC, 2016; IUCN, 2016). Barrenground caribou have a generation time of seven to nine years (COSEWIC, 2016; IUCN, 2016), meaning a threegeneration period would be approximately $21-27$ years. Our cycle analysis indicates some subpopulations (e.g., Qamanirjuaq and Western Arctic) can have cycle period lengths greater than 50 years (Table 2), which means that naturally occurring periods of increase or decline could last longer than three-generations for some barren-ground caribou subpopulations. Cyclic barren-ground caribou subpopulations neither increase exponentially without bound, nor decline exponentially to extirpation unless they are perturbed by novel ecological, climatological, or anthropogenic mechanisms. Status determinations based on exponential or linear trends over a three-generation period may be inappropriate for cyclic species.

Our pooled population abundance estimate (Figs. 4, 11) suggests that barren-ground caribou species numbers experience natural fluctuations in abundance that can result in prolonged ( $>$ three generations) periods of growth 


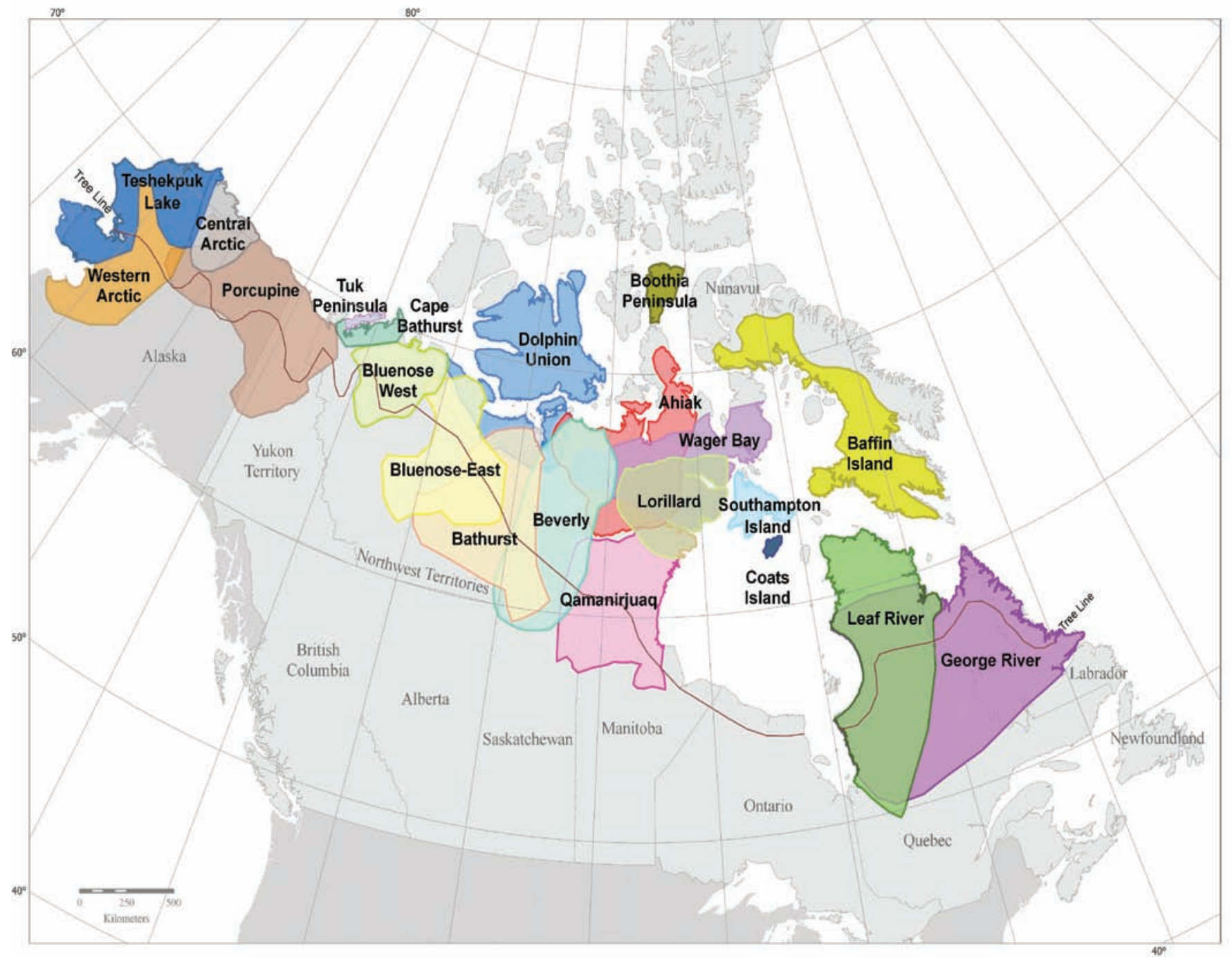

FIG. 10. Barren-ground caribou subpopulation home ranges are determined through telemetry analysis of movements and fidelity to calving grounds. Barrenground caribou partake in regular seasonal migrations, migrating north in the spring to calve on the snow covered barrens, and south in the fall to winter in the boreal forest. Subpopulation home ranges tend to expand and contract relative to population abundance. Migration between subpopulations has been documented, and continental subpopulations of barren-ground caribou are genetically undistinguishable. Our use of the term "subpopulation" is strictly in a demographic (not genetic) context and assumes demographic closure is sufficient to render exchange with other subpopulations negligible with respect to population dynamics.

or decline, including declines greater than $50 \%$. Sinecyclic subpopulations, by definition, spend half of their cycle at numbers below $50 \%$ of maximum levels. Periods of growth and decline are asynchronous between different subpopulations; this is apparent by the observed differences in cycle period lengths (Table 2). Subpopulations with larger amplitudes and greater maximum numbers (e.g., George River or Qamanirjuaq; Table 2) can dominate species or pooled subpopulation dynamics, obscuring any progressive changes to smaller subpopulations and imply a synchronous increase or decline across all subpopulations when no such synchrony exists.

The COSEWIC (2016) barren-ground caribou pooled population estimate included nine subpopulations (Tuktoyaktuk Peninsula, Beverly, Ahiak, Lorillard, Wager Bay, Boothia Peninsula, Southampton Island, Coats Island, and Baffin Island) that did not have a sufficient number of subpopulation estimates for our function fit analysis
(Fig. 12). The COSEWIC (2016) report also excluded the George River and Leaf River subpopulations as well as the three Alaskan (Central Arctic, Teshekpuk Lake, and Western Arctic) subpopulations from their pooled estimate (Fig. 12). A comparison between the COSEWIC (2016) exponential fit and our sine cycle extrapolations that included only the six subpopulations sampled in common (Qamanirjuaq, Bathurst, Bluenose-East, Bluenose-West, Cape Bathurst, and Porcupine; Fig. 12) yielded a similar pooled 2015 subpopulation abundance estimate (COSEWIC estimate $=537549$; sine-cyclic estimate $=587841)($ Fig. 11) . The close correspondence between qualitatively distinct population projection methods emphasizes the difficulty in discriminating between naturally occurring cycle declines and human-caused population declines over a short time frame relative to cycle period (Fig. 11).

In addition to population abundance criteria, COSEWIC and the IUCN Redbook status designation systems 


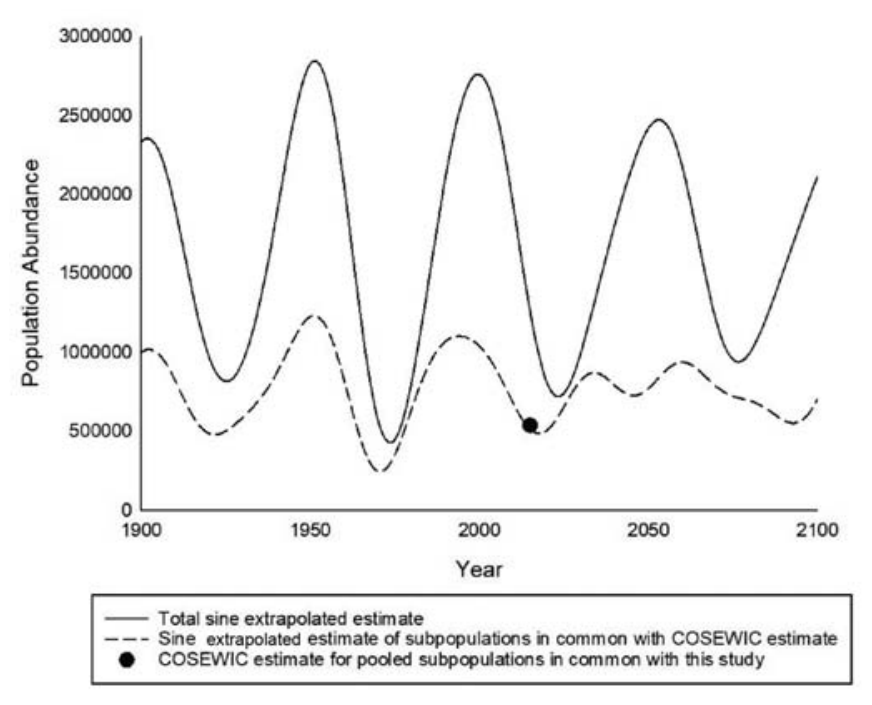

FIG. 11. The time series of pooled estimates of North American barrenground caribou subpopulations based on our sine-cyclic extrapolation for the George River, Leaf River, Qamanirjuaq, Bathurst, Bluenose-East, BluenoseWest, Cape Bathurst, Porcupine, Central Arctic, Teshekpuk Lake, and Western Arctic subpopulations is charted. We also produced a sine-cyclic extrapolation based on six subpopulations that were sampled in common with the COSEWIC (2016) report (Qamanirjuaq, Bathurst, Bluenose-East, Bluenose-West, Cape Bathurst, and Porcupine). Our sine-cyclic estimate of 587841 closely corresponded with COSEWIC's 2015 estimate of 537549 for common subpopulations.

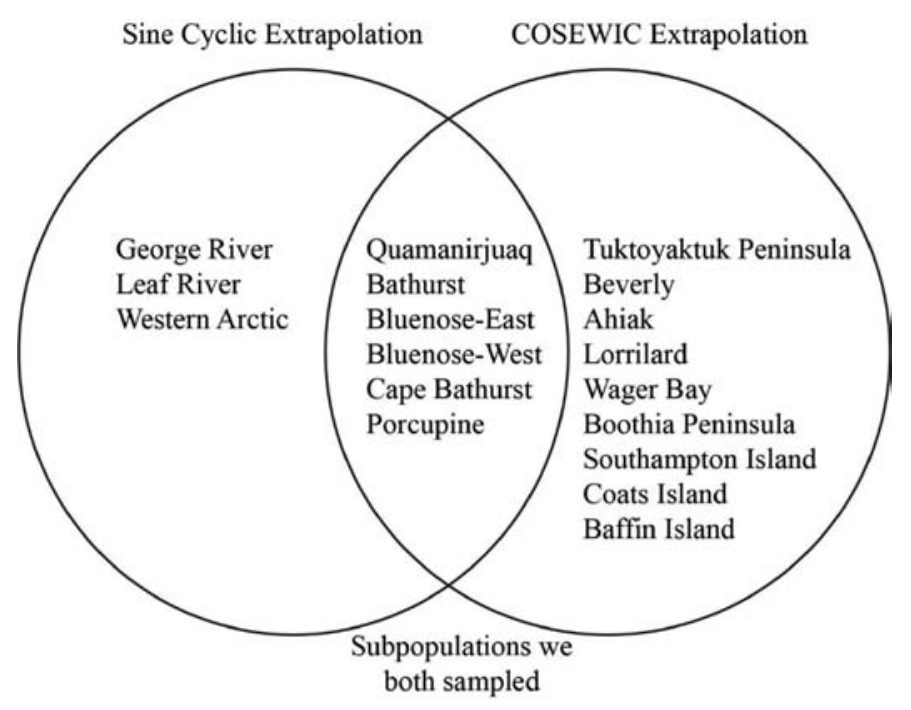

FIG. 12. We had a sufficient amount of census data to fit a sine function to 11 subpopulations of North American barren-ground caribou (i.e., George River, Leaf River, Qamanirjuaq, Bathurst, Bluenose-East, BluenoseWest, Cape Bathurst, Porcupine, Central Arctic, Teshekpuk Lake, and Western Arctic). The COSEWIC (2016) report extrapolated estimates for 15 subpopulations of barren-ground caribou (Tuktoyaktuk Peninsula, Beverly, Ahiak, Lorillard, Wager Bay, Boothia Peninsula, Southampton Island, Coats Island, Baffin Island, Qamanirjuaq, Bathurst, Cape Bathurst, Bluenose-East, Bluenose-West, Porcupine) based on linear or exponential trends over a threegeneration period. We compared our sine-cyclic extrapolation to COSEWIC's three-generation trend extrapolation based on six subpopulations that we both sampled.

incorporate other information before making final status assessments (COSEWIC, 2016). Disturbance and habitat loss (from industrial exploration and development), over-hunting, climate change, and contaminants are believed to present significant risks to barren-ground subpopulations (Adamczewski et al., 2013; COSEWIC, 2016; M. Campbell, pers. comm. 2020). Our study found no evidence of progressive demographic impacts to barren-ground caribou for any of the nine sine-cyclic subpopulations up to 2017, except for the previously discussed linear increase in the Porcupine subpopulation. However, we caution that mitigation measures and harvest management protocols may have thus far reduced negative demographic impacts to undetectable levels. We suggest that historical barren-ground caribou subpopulation sine cycles could serve as a baseline for detecting both singlefactor and cumulative impacts on barren-ground caribou subpopulation demography within a given management context. We suggest increasing the monitoring frequency of barren-ground subpopulations to ensure the entire cycle period is sampled symmetrically so that any progressive changes to baseline period length and amplitude value can be detected and to better understand the population dynamics of barren-ground subpopulations that experience irregular fluctuations. Changes to subpopulation period and amplitude could serve as monitoring indicators for direct and cumulative impacts on affected barren-ground caribou subpopulations.

\section{ACKNOWLEDGEMENTS}

The paper was improved by suggestions and comments from anonymous reviewers and the editor. M. Hebblewhite and P. McLoughlin offered insightful and positive criticism of our initial manuscript and a subsequent revision. We acknowledge useful discussions with M. Campbell, T. Hegel, D. Cluff, T. Arnold, and D. Paetkau on portions of the manuscript. This work was supported by graduate fellowships to the senior author from Lakehead University. The results, interpretations, conclusions, and any errors are entirely our own and do not necessarily represent the views of any other individual, agency, or institution. The data for this paper were entirely taken from public sources. We acknowledge those who collected these data and made them open-source available.

\section{REFERENCES}

(A)ATSR Science Team. 2009. Review of remotely sensed land surface temperature (LST) products and applications. (A) ATSR Exploitation Plan Volume 5, Issue 1. 37 p. https://atsrsensors.org/pdf/(A)ATSR\%20Exploitation\%20 Plan\%20Volume\%205\%20(Issue\%201).pdf

Adamczewski, J., Nishi, J., Gunn, A., Antonuik, T., Johnson, C., Russell, D., Blondin, et al. 2013. Modeling cumulative effects in barren-ground caribou range: Proceedings of a workshop in Yellowknife, February 2008. Manuscript Report No. 223. Yellowknife: Government of Northwest Territories. 90 p. 
Adamczewski, J., Boulanger, J., Sayine-Crawford, H., Nishi, J., Cluff, D., Williams, J., and LeClerc, L.M. 2019. Estimates of breeding females \& adult herd size and analyses of demographics for the Bathurst herd of barren-ground caribou: 2018 calving ground photographic survey. Manuscript Report No. 279. Yellowknife: Government of Northwest Territories. $140 \mathrm{p}$.

ADFG (Alaska Department of Fish and Game). 2017. Central Arctic caribou herd news, winter 2016-17. Fairbanks, Alaska: Division of Wildlife Conservation. $6 \mathrm{p}$.

Aho, K., Derryberry, D., and Peterson, T. 2014. Model selection for ecologists: The worldviews of AIC and BIC. Ecology 95(3):631-636.

https://doi.org/10.1890/13-1452.1

Ahti, T. 1959. Studies on the caribou lichen stands of Newfoundland. Annales Botanici Societatis Zoologicae-Botanicae Fennicae Vanamo 30(4). Helsinki: Societas Zoologica Botanica Fennica Vanamo. 44 p.

Anbazhagan, S., and Paramasivam, C.R. 2016. Statistical correlation between land surface temperature (LST) and vegetation index (NDVI) using multi-temporal Landsat TM data. International Journal of Advanced Earth Science and Engineering. 5:333-346.

https://doi.org/10.23953/cloud.ijaese.204

Anderson, T.A., and Johnson, C.J. 2014. Distribution of barrenground caribou during winter in response to fire. Ecosphere 5(10): Article 140.

https://doi.org/10.1890/ES14-00010.1

Archer, S., and Tieszen, L.L. 1980. Growth and physiological responses of tundra plants to defoliation. Arctic and Alpine Research 12(4):531-552.

https://doi.org/10.2307/1550499

Boulanger, J., Poole, K.G., Gunn, A., and Wierzchowski, J. 2012. Estimating the zone of influence of industrial developments on wildlife: A migratory caribou Rangifer tarandus groenlandicus and diamond mine case study. Wildlife Biology 18(2):164-179. https://doi.org/10.2981/11-045

Bowyer, T.R., Bleich, V.C., Stewart, K.M., Whiting, J.C., and Monteith, K.L. 2014. Density-dependence in ungulates: A review of causes, and concepts with some clarifications. California Fish and Game 100(3):550-572.

Boyce, M.S. 1989. The Jackson elk herd: Intensive wildlife management in North America. Cambridge: Cambridge University Press.

Burnham, K.P., and Anderson, D.R. 2002. Model selection and multimodel inference: A practical information-theoretic approach, 2nd ed. New York: Springer-Verlag.

CARMA (CircumArctic Rangifer Monitoring and Assessment Network). 2016. Interactive map.

http://carma.caff.is/index.php/carma-interactive-map

Caughley, G. 1977. Analysis of vertebrate populations. London: John Wiley \& Sons. 234 p.

Clutton-Brock, T.H., Major, M., Albon, S.D., and Guinness, F.E. 1987. Early development and population dynamics in Red Deer. I. Density-dependent effects on juvenile survival. Journal of Animal Ecology 56(1):53-67.

https://doi.org/10.2307/4799
Collins, W.B. 2006. Habitat use, foraging behavior, and nutritional ecology of Nelchina caribou. Federal Aid Research Final Performance Report. Juneau: Division of Wildlife Conservation, Alaska Department of Fish and Game. 5 p. https://www.adfg.alaska.gov/static/home/library/pdfs/ wildlife/research_pdfs/ca-habnelchina06.pdf

Collins, W.B., Dale, B.W., Adams, L.G., McElwain, D.E., and Joly, K. 2011. Fire, grazing history, lichen abundance, and winter distribution of caribou in Alaska's taiga. Journal of Wildlife Management 75(2):369-377.

https://doi.org/10.1002/jwmg.39

COSEWIC (Committee on the Status of Endangered Wildlife in Canada). 2016. COSEWIC assessment and status report on the caribou (Rangifer tarandus), barren-ground population in Canada - 2016. Ottawa, Ontario: COSEWIC. 123 p.

Council of Canadian Academies. 2014. Aboriginal food security in northern Canada: An assessment of the state of knowledge. Ottawa, Ontario: Expert Panel on the State of Knowledge of Food Security in Northern Canada, Council of Canadian Academies. 296 p.

Couturier, S., Brunelle, J., Vandal, D., and St-Martin, G. 1990. Changes in the population dynamics of the George River caribou herd, 1976-87. Arctic 43(1):9-20.

https://doi.org/10.14430/arctic1586

Cronin, M.A. 2006. A proposal to eliminate redundant terminology for intra-species groups. Wildlife Society Bulletin 34(1):247-241.

https://doi.org/10.2193/0091-7648(2006)34[237:APTERT]2.0. $\mathrm{CO} ; 2$

Demerec, M., Organizer. 1957. Population studies: Animal ecology and demography. Cold Spring Harbor Symposia on Quantitative Biology 22. Cold Spring Harbor, New York: The Biological Laboratory.

Dumond, M. 2007. Western Kitikmeot caribou workshop. Final Wildlife Report, No. 19. Kugluktuk: Department of Environment, Government of Nunavut. 47 p.

Dyke, A.S. 2005. Late Quaternary vegetation history of northern North America based on pollen, macrofossil, and faunal remains. Géographie physique et Quaternaire 59(2-3):211 - 262. https://doi.org/10.7202/014755ar

Dziak, J.J., Coffman, D.L., Lanza, S.T., Li, R., and Jermiin, L.S. 2020. Sensitivity and specificity of information criteria. Briefings in Bioinformatics 21(2):553-565. https://doi.org/10.1093/bib/bbz016

Fancy, S.G., Pank, L.F., Whitten, K.R., and Regelin, W.L. 1989. Seasonal movements of caribou in Arctic Alaska as determined by satellite. Canadian Journal of Zoology 67(3):644-650. https://doi.org/10.1139/z89-093

Fauchald, P., Park, T., Tømmervik, H., Myneni, R., and Hausner, V.H. 2017. Arctic greening from warming promotes declines in caribou populations. Science Advances 3(4): e1601365. https://doi.org/10.1126/sciadv.1601365

Ferguson, M.A.D., Williamson, R.G., and Messier, F. 1998. Inuit knowledge of long-term changes in a population of Arctic tundra caribou. Arctic 51(3): 201-219.

https://doi.org/10.14430/arctic1062 
Fowler, C.W. 1981. Density-dependence as related to life history strategy. Ecology 62(3):602-610. https://doi.org/10.2307/1937727

Gillman, L.N., Wright, S.D., Cusens, J., McBride, P.D., Malhi, Y., and Whittaker, R.J. 2015. Latitude, productivity, and species richness. Global Ecology and Biogeography 24(1):107-117. https://doi.org/10.1111/geb.12245

GLOBE. 2017. Calculating net primary productivity. Durham: University of New Hampshire; Prague, Czech Republic: Charles University. 3 p.

https://www.globe.gov/documents/355050/41927208/ CalculatingNPP.pdf/84ea6f4b-29a7-4d2a-82d8-4653104b8610

GNWT (Government of Northwest Territories). 2007. Summary: 2007 Barren-ground caribou calving distribution surveys, Northwest Territories \& Nunavut. Environment \& Natural Resources, Government of the Northwest Territories. $18 \mathrm{p}$. https://www.wrrb.ca/sites/default/files/2007\%20Barren\%20 ground $\% 20$ caribou $\% 20$ calving\%20distribution.pdf

Gonsamo, A., and Chen, J.M. 2018. Vegetation primary productivity. Reference Module in Earth Systems and Environmental Sciences. Comprehensive Remote Sensing $3: 163-189$. https://doi.org/10.1016/B978-0-12-409548-9.10535-4

Gunn, A. 2003. Voles, lemmings and caribou - population cycles revisited? Rangifer 23(5):105-111. https://doi.org/10.7557/2.23.5.1689

Gunn, A., and Miller, F.L. 1986. Traditional behavior and fidelity to caribou calving grounds by barren-ground caribou. Rangifer 6(2):151-158. https://doi.org/10.7557/2.6.2.640

Gunn, A., Russell, D., and Eamer, J. 2010. Northern caribou population trends in Canada. Canadian Biodiversity: Ecosystem Status and Trends 2010. Technical Thematic Report No. 10. Ottawa, Ontario: Canadian Councils of Resource Ministers. $74 \mathrm{p}$.

GY (Government of Yukon). 2015. Barren-ground caribou. Whitehorse: Yukon Wildlife.

http://www.env.gov.yk.ca/animals-habitat/mammals/ barrengroundcaribou.php

Hebert, L.C. 2015. "In search of deer": A historical ecological perspective on caribou in northern Manitoba in the context of Cree use. MNRM thesis, Natural Resources Institute, University of Manitoba, Winnipeg.

Hemming, J.E. 1971. The distribution movement patterns of caribou in Alaska. Alaska Department of Fish and Game Technical Bulletin No. 1.

_ _ 1975. Population growth and movement patterns of the Nelchina caribou herd. In: Luick, J.R., Lent, P.C., Klein, D.R., and White, R.G., eds. Proceedings of the First International Reindeer and Caribou Symposium, 9-11 August 1972, University of Alaska, Fairbanks, Alaska. Biological Papers of the University of Alaska, Special Report 1. 162-169. https://www.arlis.org/docs/vol1/Susitna/27/APA2729.pdf
Hicke, J.A., Asner, G.P., Randerson, J.T., Tucker, C., Los, S., Birdsey, R., Jenkins, J.C., and Field, C. 2002. Trends in North American net primary productivity derived from satellite observations, 1982-1998. Global Biogeochemical Cycles 16(2):2-1-2-14.

https://doi.org/10.1029/2001GB001550

Hurvich, C.M., and Tsai, C.-L. 1989. Regression and time series model selection in small samples. Biometrika 76(2):297-307. https://doi.org/10.1093/biomet/76.2.297

IBM Corp. 2017. IBM SPSS statistics for windows, version 25.0. Armonk, New York: IBM Corp.

IUCN (International Union for the Conservation of Nature). 2016. The IUCN red list of threatened species, Version 2016.1. International Union for the Conservation of Nature and Natural Resources Gland, Switzerland: IUCN.

Jandt, R.R., Meyers, C.R., and Cole, M.J. 2003. Western Arctic caribou herd winter habitat monitoring and utilization, 1995-1996. BLM-Alaska Open File Report 88. Anchorage: U.S. Department of the Interior, Bureau of Land Management, Alaska State Office. 31 p.

Joly, K., Klein, D.R., Verbyla, D.L., Rupp, S., and Chapin, F.S., III. 2011. Linkages between large-scale climate patterns and the dynamics of Arctic caribou populations. Ecography 34(2):345-352.

https://doi.org/10.1111/j.1600-0587.2010.06377.x

Kelsall, J.P. 1968. The migratory barren-ground caribou of Canada. Ottawa, Ontario: Canadian Wildlife Service, Department of Indian and Northern Affairs. 340 p.

Kie, J.G., and White, M. 1985. Population dynamics of whitetailed deer (Odocoileus virginianus) on the Welder Wildlife Refuge, Texas. The Southwestern Naturalist 30(1):105-118. https://doi.org/10.2307/3670664

Klein, D.R. 1970. Food selection by North American deer and their response to over-utilization of preferred plant species. In: Watson, A., ed. Animal populations in relation to their food resources. Symposium 10 of the British Ecological Society, 24-28 March 1969, Aberdeen, Scotland. Oxford: Blackwell Scientific Publications. 25-46.

1986. Latitudinal variation in foraging strategies. In: Gudmundsson, O., ed. Grazing research at northern latitudes. New York: Plenum Press. 237-246. https://doi.org/10.1007/978-1-4757-5338-7_23،

___ 1991. Limiting factors in caribou population ecology. Rangifer 11(4):30-35.

https://doi.org/10.7557/2.11.4.990

Legat, A., Chocolate, G., Gon, B., Zoe, S.A., and Chocolate, M. 2014. Caribou migration and the state of their habitat: Tłicho knowledge and perspective on ?ekwò̀, (barrenland caribou). Tłịchǫ Traditional Knowledge Reports: Series 2. Behchokò, Northwest Territories: Dedats'eetsaa: Tłịchǫ Research and Training Institute.

https://research.tlicho.ca/sites/default/files/105-caribou_ migration_report-web.pdf 
Leyequien, E., Verrelst, J., Slot, M., Schaepman-Strub, G., Heitkönig, I.M.A., and Skidmore, A. 2007. Capturing the fugitive: Applying remote sensing to terrestrial animal distribution and diversity. International Journal of Applied Earth Observation and Geoinformation 9(1):1-20.

https://doi.org/10.1016/j.jag.2006.08.002

Liu, Z., Jian, Z., Yoshimura, K., Buenning, N.K., Poulsen, C.J., and Bowen, G.J. 2015. Recent contrasting winter temperature changes over North America linked to enhanced positive Pacific-North American pattern. Geophysical Research Letters. 42(18): $7750-7757$. https://doi.org/10.1002/2015GL065656

Manseau, M., Huot, J., and Crete, M. 1996. Effects of summer grazing by caribou on composition and productivity of vegetation: Community and landscape level. Journal of Ecology 84(4):503-513. https://doi.org/10.2307/2261473

May, R.M. 1976. Simple mathematical models with very complicated dynamics. Nature 261:459-467. https://doi.org/10.1038/261459a0

McCullough, D.R. 1979. The George Reserve deer herd: Population ecology of a K-selected species. Ann Arbor: University of Michigan Press.

___ 1999. Density-dependence and life-history strategies of ungulates. Journal of Mammalogy 80(4):1130-1146. https://doi.org/10.2307/1383164

McFarlane, K., Gunn, A., Campbell, M., Dumond, M., Adamczewski, J., and Wilson, G.A. 2016. Genetic diversity, structure and gene flow of migratory barren-ground caribou (Rangifer tarandus groenlandicus) in Canada. Rangifer 36(1):1-24.

https://doi.org/10.7557/2.36.1.3577

Meldgaard, M. 1986. The Greenland caribou - zoogeography, taxonomy, and population dynamics. Meddelelser om Grønland: Bioscience 20. 88 p.

Messier, F., Huot, J., Le Henaff, D., and Luttich, S. 1988. Demography of the George River caribou herd: Evidence of population regulation by forage exploitation and range expansion. Arctic 41(4):279-287.

https://doi.org/10.14430/arctic1733

Mills, L.S., and Allendorf, F.W. 1996. The one-migrant-pergeneration rule in conservation and management. Conservation Biology 10(6):1509-1518.

https://doi.org/10.1046/j.1523-1739.1996.10061509.x

Mysterud, A. 2006. The concept of overgrazing and its role in management of large herbivores. Wildlife Biology 12(2):129-141.

https://doi.org/10.2981/0909-6396(2006)12[129:TCOOAI]2.0. $\mathrm{CO} ; 2$

Nagy, J.A., and Campbell, M.W. 2012. Herd structure, movements, calving grounds, activity periods, home range similarity, and behaviours of migratory and tundra-wintering barren-ground caribou on mainland Nunavut and eastern mainland Northwest Territories, Canada. Technical Report Series 2012 - No. 01-12. Arviat: Department of Environment, Government of Nunavut.
Nagy, J.A., Johnson, D.L., Larter, N.C., Campbell, M.W., Derocher, A.E., Kelly, A., Dumond, M., Allaire, D., and Croft, B. 2011. Subpopulation structure of caribou (Rangifer tarandus L.) in Arctic and Subarctic Canada. Ecological Applications 21(6):2334-2348. https://doi.org/10.1890/10-1410.1

NEO (NASA Earth Observations). 2018. Net primary productivity (1 month -TERRA/MODIS).

https://neo.sci.gsfc.nasa.gov/view.php?dataset Id =MOD17A2_M_PSN

Nicholson, K. L., Arthur, S. M., Horne, J. S., Garton, E.O., and Del Vecchio, P. A. 2016. Modeling caribou movements: Seasonal ranges and migration routes of the Central Arctic Herd. PLoS ONE 11(4): e0150333.

https://doi.org/10.1371/journal.pone.0150333

Norusis, M.J. 2010. PASW statistics 18 statistical procedures companion. Upper Saddle River, New Jersey: Prentice Hall.

Parker, K.L., Barboza, P.S., and Stephenson, T.R. 2005. Protein conservation in female caribou (Rangifer tarandus): Effects of decreasing diet quality during winter. Journal of Mammalogy 86(3):610-622.

https://doi.org/10.1644/1545-1542(2005)86[610:PCIFCR]2.0. $\mathrm{CO} ; 2$

Parlee, B.L., Sandlos, J., and Natcher, D.C. 2018. Undermining subsistence: Barren-ground caribou in a "tragedy of open access." Science Advances 4(2): e1701611.

https://doi.org/10.1126/sciadv.1701611

Payette, S., Fortin, M.-J., and Gamache, I. 2001. The Subarctic forest - Tundra: The structure of a biome in a changing climate: The shifting of local Subarctic tree lines throughout the forest-tundra biome, which is linked to ecological processes at different spatiotemporal scales, will reflect future global changes in climate. BioScience 51(9):709-718.

https://doi.org/10.1641/0006-3568(2001)051[0709:TSFTTS]2.0. $\mathrm{CO} ; 2$

Post, E., Forchhammer, M.C., Bret-Harte, M.S., Callaghan, T.V., Christensen, T.R., Elberling, B., Fox, A.D., et al. 2009. Ecological dynamics across the Arctic associated with recent climate change. Science 325(5946):1355-1358.

https://doi.org/10.1126/science.1173113

Qian, H. 1999. Spatial pattern of vascular plant diversity in North America north of Mexico and its floristic relationship with Eurasia. Annals of Botany 83(3):271 - 283.

https://doi.org/10.1006/anbo.1998.0816

Raynolds, M.K., Comiso, J.C., Walker, D.A., and Verbyla, D. 2008. Relationship between satellite-derived land surface temperatures, Arctic vegetation types, and NDVI. Remote Sensing of Environment 112(4):1884-1894. https://doi.org/10.1016/j.rse.2007.09.008

RCGS (Royal Canadian Geographical Society). 2010. Return to the wild. Evolving perspectives on Canadian wildlife. Species: Barren-ground caribou. Ottawa, Ontario: RCGS.

Renshaw, E. 1991. Modelling biological populations in space and time. Cambridge: Cambridge University Press. 350 p. https://doi.org/10.1017/CBO9780511624094 
Rickbeil, G.J.M., Hermosilla, T., Coops, N.C., White, J.C., and Wulder, M.A. 2017. Estimating changes in lichen mat volume through time and related effects on barren ground caribou (Rangifer tarandus groenlandicus) movement. PLoS ONE 12(3): e0172669. https://doi.org/10.1371/journal.pone.0172669

Russell, D.E., Kofinas, G., and Griffith, B. 2002. Barren-ground caribou calving ground workshop report of proceedings. Technical Report Series No. 390. Ottawa, Ontario: Canadian Wildlife Service.

Schmid, J.N. 2017. Using Google Earth Engine for Landsat NDVI time series analysis to indicate the present status of forest stands. BSc thesis, Faculty of Geoscience and Geography, Georg-August-Universität, Göttingen, Germany.

Schwarz, G. 1978. Estimating the dimension of a model. Annals of Statistics 6(2):461-464.

https://doi.org/10.1214/aos/1176344136

Scotter, G.W. 1964. Effects of forest fires on the winter range of barren-ground caribou in northern Saskatchewan. Wildlife Management Bulletin, Series 1, No. 18. Ottawa, Ontario: Canadian Wildlife Service. 109 p.

Sidhu, N., Pebesma, E., and Câmara, G. 2018. Using Google Earth Engine to detect land cover change: Singapore as a use case. European Journal of Remote Sensing 51(1):486-500. https://doi.org/10.1080/22797254.2018.1451782

Skogland, T. 1985. The effects of density-dependent resource limitations on the demography of wild reindeer. Journal of Animal Ecology 54(2):359-374.

https://doi.org/10.2307/4484

Skoog, R. O. 1968. Ecology of caribou in Alaska. PhD thesis, University of California-Berkley.

SPSS Inc. 2001. The SPSS twostep cluster component: A scalable component enabling more efficient customer segmentation. White paper - technical report. Chicago, Illinois: SPSS Inc.

Sugiura, N. 1978. Further analysts of the data by Akaike's informationcriterionand thefinitecorrections. Communications in Statistics - Theory and Methods 7(1):13-26. https://doi.org/10.1080/03610927808827599

Tanner, J.T. 1966. Effects of population density on growth rates of animal populations. Ecology 47(5):733-745. https://doi.org/10.2307/1934260

Théau, J., Peddle, D.R., and Duguay, C.R. 2005. Mapping lichen in a caribou habitat of northern Québec, Canada, using an enhancement-classification method and spectral mixture analysis. Remote Sensing of Environment 94(2):232 - 243. https://doi.org/10.1016/j.rse.2004.10.008

Thomas, D.C., and Hervieux, D.P. 1986. The late winter diets of barren-ground caribou in north-central Canada. Rangifer 6(2):305-310.

https://doi.org/10.7557/2.6.2.663
Thorpe, N.L., Eyegetok, S., Hakongak, N., and Qitirmuit Elders 2001. Tuktu and Nogak project: A caribou chronicle. Final Report to the West Kitikmeot Slave/Study Society. Ikalukuuttiak, Northwest Territories. 198 p.

Torrence, C., and Compo, G.P. 1998. A practical guide to wavelet analysis. Bulletin of the American Meteorological Society 79(1):61-78.

https://doi.org/10.1175/1520-0477(1998)079<0061:APGTWA> 2.0.CO;2

Vandermeer, J. 2010. How populations grow: The exponential and logistic equations. - Nature Education Knowledge 3(10): 15.

Venables, W.N., and Ripley, B.D. 2002. Modern applied statistics with S, 4th ed. New York: Springer Science+Business Media. $504 \mathrm{p}$.

https://doi.org/10.1007/978-0-387-21706-2

Weier, J., and Herring, D. 2000. Measuring vegetation (NDVI and EVI). Greenbelt, Maryland: NASA Earth Observatory, NASA Goddard Space Flight Center.

https://earthobservatory.nasa.gov/features/Measuring Vegetation

Weladji, R.B., and Holland, Ø. 2003. Global climate change and reindeer: Effects of winter weather on the autumn weight and growth of calves. Oecologia 136:317-323.

https://doi.org/10.1007/s00442-003-1257-9

Wilson, D.E., and Reeder, D.M., eds. 2005. Rangifer tarandus. In: Wilson and Reeder's mammal species of the world: A taxonomic and geographic reference, 3rd ed. 2 vols. Baltimore, Maryland: Johns Hopkins University Press/Bucknell University.

WRRB (Wek'èezhìi Renewable Resource Board). 2020. Government of the Northwest Territories and Tłıcho Government Joint Proposal on Management Actions for Wolves (diga) on the Bathurst and Bluenose-East Barrenground Caribou (rekwò) Herd Winter Ranges: 2020 - 2025. Northwest Territories: WRRB. 19 p.

https://www.wrrb.ca/sites/default/files/LT\%20WRRB\%20 from $\% 20$ TG $\% 20$ and $\% 20$ ENR $\% 20$ January $\% 2031 \% 20$ $2020 \% 20$ Joint $\% 20$ Wolf\%20Mgmt\%20Proposal\%20FINAL. pdf

Yap, B.W., and Sim, C.H. 2011. Comparisons of various types of normality tests. Journal of Statistical Computation and Simulation 81(12):2141-2155.

https://doi.org/10.1080/00949655.2010.520163

Yu, Y., Lui, Y., and Yu, P. 2018. 5.12 - Land surface temperature product development for JPSS and GOES-R Missions. Comprehensive Remote Sensing 5:284-303. https://doi.org/10.1016/B978-0-12-409548-9.10522-6

Zalatan, R., Gunn, A., and Henry, G.H.R. 2006. Long-term abundance patterns of barren-ground caribou using trampling scars on roots of Picea mariana in the Northwest Territories, Canada. Arctic, Antarctic, and Alpine Research 38(4):624-630. https://doi.org/10.1657/1523-0430(2006)38[624:LAPOBC]2.0. $\mathrm{CO} ; 2$

Zhang, X.Q., Zheng, J.B., and Gao, H. 2000. Comparison of wavelet transform and Fourier self-deconvolution (FSD) and wavelet (FSD) for curve fitting. Analyst 125(5):915-919. https://doi.org/10.1039/b000064g 